\title{
Role of calcitonin gene-related peptide in cerebral vasospasm, and as a therapeutic approach to subarachnoid hemorrhage
}

\author{
Stelios Kokkoris ${ }^{1}$, Peter Andrews ${ }^{2} *$ and David J. Webb ${ }^{3}$ \\ 1 Intensive Care Unit, Western General Hospital, Edinburgh, UK \\ ${ }^{2}$ Centre for Clinical Brain Sciences, University of Edinburgh, Edinburgh, UK \\ ${ }^{3}$ Clinical Pharmacology Unit, British Heart Foundation Centre for Cardiovascular Science, Queen's Medical Research Institute, \\ University of Edinburgh, Edinburgh, UK
}

\section{Edited by:}

Hubert Vaudry, University of Rouen, France

\section{Reviewed by:}

Akiyoshi Takahashi, Kitasato

University, Japan

Jo G. De Mey, Maastricht University, Netherlands

\section{${ }^{*}$ Correspondence:}

Peter Andrews, Centre for Clinical

Brain Sciences, University of

Edinburgh, Edinburgh, UK.

e-mail:p.andrews@ed.ac.uk
Calcitonin gene-related peptide (CGRP) is one of the most potent microvascular vasodilators identified to date. Vascular relaxation and vasodilation is mediated via activation of the CGRP receptor. This atypical receptor is made up of a $\mathrm{G}$ protein-coupled receptor called calcitonin receptor-like receptor (CLR), a single transmembrane protein called receptor activity-modifying protein (RAMP), and an additional protein that is required for $\mathrm{Ga}_{\mathrm{s}}$ coupling, known as receptor component protein (RCP). Several mechanisms involved in CGRP-mediated relaxation have been identified. These include nitric oxide (NO)-dependent endothelium-dependent mechanisms or cAMP-mediated endothelium-independent pathways; the latter being more common. Subarachnoid hemorrhage (SAH) is associated with cerebral vasoconstriction that occurs several days after the hemorrhage and is often fatal. The vasospasm occurs in $30-40 \%$ of patients and is the major cause of death from this condition. The vasoconstriction is associated with a decrease in CGRP levels in nerves and an increase in CGRP levels in draining blood, suggesting that CGRP is released from nerves to oppose the vasoconstriction. This evidence has led to the concept that exogenous CGRP may be beneficial in a condition that has proven hard to treat. The present article reviews: (a) the pathophysiology of delayed ischemic neurologic deficit after SAH (b) the basics of the CGRP receptor structure, signal transduction, and vasodilatation mechanisms and (c) the studies that have been conducted so far using CGRP in both animals and humans with SAH.

Keywords: GPCR, CGRP, subarachnoid hemorrhage, cerebral vasospasm, G proteins

\section{INTRODUCTION}

In the US, over 30,000 persons each year experience a subarachnoid hemorrhage (SAH). Whereas intracranial aneurysms are found in $2-5 \%$ of all autopsies, the incidence of rupture is only $2-20 / 100,000$ individuals/year (Ingall et al., 2000). SAH is more frequent in women than men (3:2 ratio) over the age of 40 , but the reverse is the case in those younger than 40 (The ACROSS Group, 2000; Ohkuma et al., 2002). Peak rupture rates occur between the ages of 50 and 60 years (The ACROSS Group, 2000; Ohkuma et al., 2002). Intracranial aneurysms account for approximately $85 \%$ of cases of non-traumatic SAH, whereas $10 \%$ have the pattern of non-aneurysmal perimesencephalic hemorrhage, a relatively harmless condition (van Gijn et al., 2007). The other causes include bleeding from other vascular malformations, moyamoya syndrome, coagulopathy, and, rarely, extension of an intracerebral hematoma (van Gijn etal., 2007). In up to $15 \%$, no source of bleeding is identified (Kim et al., 2012). Approximately $10-15 \%$ of patients die before receiving medical treatment from the initial bleed or its immediate complications (Huang and van Gelder, 2002) and over 40\% of hospitalized patients die within 1 month of the event (Ingall et al., 2000). Those that survive the initial bleed are at risk for a number of secondary insults including rebleeding (Winn et al., 1977; Ohkuma et al., 2001), hydrocephalus, and cerebral vasospasm (van Gijn et al., 2007).

Calcitonin gene-related peptide (CGRP) is one of the most potent microvascular vasodilator peptides identified to date. In the cerebral circulation, CGRP is released from sensory fibers originating in the trigeminal ganglia and acts to dilate cerebral vessels (McCulloch et al., 1986). CGRP has been found to be at least 1,000 times more potent than acetylcholine, substance P, ATP, adenosine, and 5-hydroxytriptamine, and 10-100 times more potent than the $\beta$-adrenergic agonist isoprenaline. Consequently, a dose of 15 pmol injected into human skin produces an erythema that lasts for 5-6 h (Brain et al., 1985). As we discuss later, CGRP has a particularly potent vasodilator activity in the cerebral circulation, rendering it a promising agent for the treatment of SAH-triggered cerebral vasospasm.

In the present review, we summarize the etiology and therapy of cerebral vasospasm, the biology of CGRP and its receptors, and review the role of CGRP as a treatment in SAH-associated vasospasm in both animals and humans. 


\section{CEREBRAL VASOSPASM AFTER SAH DEFINITIONS}

Throughout the literature, authors have used various means of defining vasospasm including terms like angiographic vasospasm, symptomatic vasospasm, and delayed cerebral ischemia (DCI). Angiographic vasospasm is a narrowing of the lumen of the major cerebral arteries, which is usually focal but may be diffuse. Vasospasm has its onset usually on day 3 after SAH, is maximal at days 6-8, and usually lasts for 2-3 weeks (Wilkins, 1990). Symptomatic vasospasm is characterized by the insidious onset of confusion and decreased level of consciousness, followed by focal motor and/or speech impairments. It is mainly a diagnosis of exclusion, when clinical deterioration occurs and hydrocephalus, rebleeding, hypoxia, and metabolic abnormalities have been ruled out. DCI is defined as symptomatic vasospasm, infarction attributable to vasospasm, or both (Frontera et al., 2009). Although about $70 \%$ of patients may develop arterial narrowing, only $30 \%$ will manifest neurological deficits. The outcome of DCI itself is death in about one-third and permanent deficit in another third (Dorsch, 1995). In the present review the term vasospasm is defined as arterial vessel narrowing.

\section{VASOSPASM PATHOPHYSIOLOGY Nitric oxide}

Loss of the biological effect of nitric oxide (NO) is considered to play a pivotal permissive role in the development of cerebral vasospasm. The principal effect of NO on cerebral vessels is the relaxation of vascular smooth muscle cells, with decreased bioavailability of NO being implicated in the formation of SAHinduced vasospasm. The depletion of NO has been assumed to occur via several mechanisms in the setting of SAH. First, due to its high affinity for hemoglobin $(\mathrm{Hb}), \mathrm{NO}$ is scavenged by $\mathrm{Hb}$ released during the breakdown of subarachnoid blood (Goretski and Hollocher, 1988; Ignarro, 1990). Second, it is possible that the production of $\mathrm{NO}$ is decreased in SAH, as a result of the down-regulation of endothelial NO synthase (eNOS) and neuronal NOS (nNOS; Pluta, 2005). This is supported by studies that revealed the down-regulation/dysfunction of eNOS, and loss of nNOS in spastic arteries after SAH (Hino et al., 1996; Pluta et al., 1996), as well as the finding that levels of asymmetric dimethylarginine (ADMA), an endogenous inhibitor of eNOS, are elevated in the setting of cerebral vasospasm (Jung et al., 2004). Third, NO may reverse the effects of the potent vasoconstrictor endothelin-1 (ET-1; Thomas et al., 1997). Therefore, in the setting of decreased NO levels, the balance of vasodilator and vasoconstrictor influences is altered, and the relatively increased actions of ET-1 can potentiate cerebral vasospasm.

\section{Endothelin-1}

ET-1 is an extremely potent vasoconstrictor. In the brain, it is primarily produced by endothelial cells in response to ischemia, though it can also be produced by neurons, astrocytes, and activated leukocytes (Fassbender et al., 2000; Chow et al., 2002; Dumont et al., 2003). Levels of ET-1 are high in the plasma and cerebrospinal fluid (CSF) of SAH patients, correlate with the persistence of cerebral vasospasm (Seifert et al., 1995; Juvela, 2000), and decline in the absence of vasospasm (Seifert et al., 1995).
Conversely, the administration of ET-1 antagonists or endothelin converting enzyme inhibitors prevents vasospasm (Kwan et al., 2002; Macdonald et al., 2008). Lastly, ET-1 induces NADPH oxidase expression and oxidative stress in human endothelial cells (Duerrschmidt et al., 2000).

\section{Inflammation}

Expression of adhesion molecules facilitates leukocyte adherence to the endothelium. Adhesion molecules, such as ICAM-1, VCAM-1, and E-selectin, have been found to be elevated in the CSF of patients with SAH and in blood vessel walls exposed to clot (Polin et al., 1998; Dumont et al., 2003). Leukocytes can contribute to vasospasm by promoting free radical formation that may evoke endothelial dysfunction (Grisham et al., 1998; Sullivan et al., 2000), and by producing a variety of vasoactive substances, including ET-1 and cytokines (Fassbender et al., 2000). Several cytokines have been found to be up-regulated in cerebral vasospasm, including TNF-alpha, IL-1, IL-6, and IL-8 (Hirashima et al., 1997; Fassbender et al., 2001; Takizawa et al., 2001).

\section{Oxidative stress}

Oxyhemoglobin (OxyHb) may catalyze generation of reactive oxygen species (ROS). Free radicals are considered to play a pivotal role in cerebral vasospasm through various mechanisms. First, they can initiate lipid peroxidation, whose products, lipid peroxides, are capable of producing vasospasm and damaging the structure of arteries (Lin et al., 2006). Second, it has been hypothesized that ROS can activate the protein kinase $\mathrm{C}$ (PKC) pathway directly and indirectly, through enhancement of the metabolism of membrane phospholipids resulting from peroxidative damage. This, in turn, can lead to vasospasm (Asano and Matsui, 1999). Other possible vasoactive compounds are bilirubin oxidation products (BOXes). Once bilirubin is formed, it is subsequently oxidized into BOXes, reaching maximum concentrations during the peak vasospasm period of 4-11 days. They are thought to be potentiators of cerebral vasospasm once it has been initiated, rather than primary initiators (Clark and Sharp, 2006).

\section{Hemoglobin}

A large body of evidence suggests that $\mathrm{OxyHb}$, the ferrous form of hemoglobin, released from lysed erythrocytes, is a mediator of vasospasm. More specifically, $\mathrm{OxyHb}$ causes prolonged contraction of isolated cerebral arteries (Toda et al., 1991), and intracisternal injections of this agent result in cerebral vasospasm (Macdonald et al., 1991). Indeed, the presence of OxyHb in the CSF of patients after SAH and the extent of hemorrhage are correlated with the distribution, severity, and time course of vasospasm (Mayberg et al., 1990). Ferrous hemoglobin released from subarachnoid clot could lead to delayed arterial narrowing by a number of mechanisms, such as scavenging or decreased production of NO (Pluta, 2005), free radical production, modification of $\mathrm{K}^{+}$and $\mathrm{Ca}^{2+}$ channels (Ishiguro et al., 2008), differential upregulation of genes (Vikman et al., 2006), and activation of the Rho/Rho kinase and PKC pathways (Wickman et al., 2003).

\section{Intracellular $\mathrm{Ca}^{2+}$}

Vasospasm can be regarded as an abnormal and prolonged contraction of vascular smooth muscle. The intracellular free $\mathrm{Ca}^{2+}$ 
level plays a pivotal role in the regulation of smooth muscle contractility (Horowitz etal., 1996). Following SAH, changes have been reported in the electrical properties of smooth muscle cells of small diameter cerebral arteries leading to enhanced $\mathrm{Ca}^{2+}$ influx, vasoconstriction, and decreased cerebral blood flow (Koide etal., 2011). Cerebral arteries from healthy animals express only L-type voltage-dependent $\mathrm{Ca}^{2+}$ channels. Expression of an additional type of voltage-dependent $\mathrm{Ca}^{2+}$ channels (R-type) occurs after $\mathrm{SAH}$, leading to increased $\mathrm{Ca}^{2+}$ channel density, increased $\mathrm{Ca}^{2+}$ influx, and vasoconstriction (Ishiguro et al., 2005).

\section{Cortical spreading depolarization}

This is a pathogenetic process that has attracted much attention lately. The term "cortical spreading depolarization" describes the wave of near-complete neuronal depolarization and neuronal swelling in the brain that is ignited when passive cation influx across the cellular membranes exceeds ATP-dependent $\mathrm{Na}^{+}$and $\mathrm{Ca}^{2+}$ pump activity. The cation influx is followed by water influx and shrinkage of the extracellular space by $\sim 70 \%$ (Dreier etal., 2009). Although the ignition of cortical spreading depolarization occurs passively, driven by electrical and diffusion forces, energy consumption paradoxically increases since $\mathrm{Na}^{+}$and $\mathrm{Ca}^{2+}$ pumps are immediately activated to correct the intracellular $\mathrm{Na}^{+}$and $\mathrm{Ca}^{2+}$ surge. As a consequence, regional cerebral blood flow increases during the neuronal depolarization phase. The opposite of this physiological hemodynamic response to cortical spreading depolarization is termed "the inverse hemodynamic response," and occurs when there is local dysfunction of the microvasculature. With the inverse response, severe microvascular spasm instead of vasodilatation is coupled to the neuronal depolarization phase, and the term "cortical spreading ischemia" describes the cortical spreading depolarization-induced perfusion deficit (Dreier et al., 2009).

\section{Neurogenic factors}

The cerebral arteries have sympathetic, parasympathetic, and sensory innervation. It has been postulated that SAH causes a derangement of neuronal regulatory mechanisms, which in turn leads to vascular smooth muscle contraction. The vasoconstriction is associated with a decrease in CGRP levels in cerebral perivascular nerves (Edvinsson et al., 1991) and an increase in CGRP levels in blood draining from the external jugular vein (Juul et al., 1990), suggesting that CGRP is released antidromically from trigeminal sensory perivascular nerves to oppose the vasoconstriction. This evidence has led to the concept that administration of CGRP may be beneficial in SAH-associated vasospasm. The molecular characteristics of CGRP and its use as a treatment option in SAH are reviewed in Sections "Calcitonin Gene-related Peptide Biology" and "Calcitonin Gene-related Peptide and SAH," respectively, of the present article.

\section{TREATMENT OF VASOSPASM}

The management of vasospasm involves routine "prophylactic" measures as well as more aggressive interventions, reserved for situations where there are signs or symptoms of DCI.

\section{Hemodynamic therapy}

The use of triple-H therapy (hypervolemia, hypertension, and hemodilution) stems from numerous clinical observations noting improvement in patients' clinical symptoms following induced hypertension and volume expansion (Kosnik and Hunt, 1976; Kassell et al., 1982). The relative contribution of each component is debated. However, there are many uncertainties for the use of prophylactic hemodynamic therapy following SAH. Two studies randomly assigned normovolemic or hypervolemic therapy to patients and reported no difference in the incidence of DCI between groups (Lennihan et al., 2000; Egge et al., 2001).

\section{Nimodipine}

Nimodipine is safe, cost-effective, and reduces the risk of poor outcome and secondary ischemia (Neil-Dwyer et al., 1987; Welty, 1987; Kostron et al., 1988; Mee etal., 1988), but has very modest effects. It is used prophylactically in all patients with SAH. Its precise mechanism of action remains unclear. Despite being shown to reduce the incidence of DCI and cerebral infarction in clinical trials, it has negligible effects on angiographic vasospasm; nimodipine may be neuroprotective by blocking $\mathrm{Ca}^{2+}$ influx at a neuronal level (Al-Tamimi et al., 2010).

\section{Intracisternal thrombolysis}

A meta-analysis looking at a total of 652 patients who were treated with intracisternal thrombolytics concluded that thrombolytic therapy had a statistically significant beneficial effect. However, the authors acknowledged the lack of large, randomized prospective trials (Amin-Hanjani et al., 2004).

\section{Endovascular techniques}

Endovascular techniques frequently play a role in the aggressive treatment of vasospasm. They include transluminal angioplasty and intra-arterial infusion of vasodilators (papaverin, nicardipine, verapamil, etc.; Brisman et al., 2006). Transluminal balloon angioplasty is very effective at reversing angiographic spasm of large proximal vessels and produces a sustained reversal of arterial narrowing (Brisman et al., 2006; Jestaedt et al., 2008). The optimal timing of angioplasty in relation to medical therapy is uncertain. Major complications occur in $\sim 5 \%$ of procedures and include vessel rupture, occlusion, dissection, hemorrhagic infarction, and hemorrhage from unsecured aneurysms (Zwienenberg-Lee et al., 2006).

\section{Statins}

Statins have been shown to possess cholesterol-loweringindependent pleiotropic effects in different clinical settings, including a decrease in the incidence and duration of severe vasospasm as well as a reduction in the mortality rate after SAH (Lynch et al., 2005; Tseng et al., 2005, 2007). Statins are thought to be beneficial in the prevention of cerebral vasospasm by down-regulating inflammation and up-regulating the expression of eNOS and therefore NO (Sugawara et al., 2011).

\section{Other treatments}

Clazosentan, an endothelin receptor $\mathrm{A}\left(\mathrm{ET}_{\mathrm{A}}\right)$ antagonist decreased the incidence of severe vasospasm, DCI and new infarcts seen on CT scans in a dose-dependent fashion. However, CONSCIOUS 1 
study (a phase 2 trial) did not show a reduction in patient mortality, though the study was underpowered for this endpoint (the primary end point of this study was moderate or severe vasospasm within 14 days; Macdonald et al., 2008). CONSCIOUS 2 study (a phase 3 trial) included 1157 patients and its primary composite end point comprised all-cause mortality and vasospasm related morbidity. This study showed that clazosentan at $5 \mathrm{mg} / \mathrm{h}$ had no significant effect on mortality and vasospasm-related morbidity or functional outcome (Macdonald et al., 2011).

Erythropoietin (EPO) has also been examined in the setting of cerebral vasospasm. Apart from being potentially neuroprotective, EPO may play a role in preventing vasospasm by increasing the phosphorylation of eNOS (Santhanam et al., 2005), a potentially important mechanism for increasing NO production.

A recent randomized controlled trial (MASH 2) including 1204 patients did not show any benefit from intravenous (i.v.) magnesium sulfate administration in clinical outcome after aneurysmal SAH (Dorhout Mees et al., 2012).

Other drugs under investigation are tirilazad, a free radical scavenger (Haley etal., 1997), fasudil, a Rho-kinase inhibitor that inhibits vascular smooth muscle contraction (Shibuya et al., 1992), sodium nitrite, an NO donor (Pluta et al., 2005) and cisternal placement of prolonged-release nicardipine-loaded polymers (Kasuya et al., 2005).

\section{CALCITONIN GENE-RELATED PEPTIDE BIOLOGY CALCITONIN GENE-RELATED PEPTIDE}

Calcitonin gene-related peptide is expressed in a subgroup of small neurons in the dorsal root, trigeminal, and vagal ganglia, which respond to noxious, thermal, or visceral input. These peptidergic neurons use L-glutamate as their primary neurotransmitter and project to the dorsal horn, trigeminal nucleus caudalis, or nucleus of the solitary tract. CGRP increases neurotransmitter release and neuronal responsiveness to noxious stimulation at all these levels, which leads to central sensitization underlying chronic pain states (Benarroch, 2011). CGRP can also be released antidromically in the periphery, eliciting vasodilatation as a component of neurogenic inflammation. CGRP may be involved in the pathophysiology of inflammatory and neuropathic pain. Involvement of CGRP in migraine headache has led to the development of CGRP antagonists for treatment of this disorder (Benarroch, 2011).

Calcitonin gene-related peptide is a 37 -amino acid neuropeptide that was identified in 1982 by molecular biological techniques in the thyroid of aging rats and medullary thyroid carcinomas in humans, which were found to contain an alternative peptide product from the calcitonin gene (Amara et al., 1982). CGRP, in common with other members of this peptide family, is derived from the calcitonin gene. Other members of this family include adrenomedulin (AM), which is a potent vasodilator, amylin (AMY), which is important for maintaining glycemic control, and calcitonin, which contributes to calcium metabolism (Hay, 2007). CGRP exists in two forms, named $\alpha$ CGRP and $\beta$ CGRP. While these two isoforms share the same biological activities, and differ by only three amino acids in the human (Steenbergh et al., 1985, 1986), they are formed from two distinct genes, which share $>90 \%$ homology, at different sites on chromosome 11. CALC I gene forms calcitonin and $\alpha$ CGRP, whereas CALC II forms $\beta$ CGRP (Alevizaki et al., 1986). aCGRP synthesis is caused by alternative splicing of the calcitonin gene (Amara et al., 1982; Figure 1). $\beta C G R P$ is known to be transcribed from its own distinct gene (Steenbergh et al., 1985, 1986). The majority of CGRP within the body is $\alpha$ CGRP and primarily expressed in the peripheral and central nervous system. $\beta$ CGRP is mainly expressed in the gut (Mulderry et al., 1988). However, it has also been identified in the central nervous system, pituitary, thyroid, and in medullary thyroid carcinoma as a major CGRP form together with $\alpha$ CGRP (Petermann et al., 1987).

Data from NMR studies suggest that CGRP consists of a characteristic N-terminal disulfide bridge-linked loop between cysteines $\mathrm{Cys}_{2}$ and $\mathrm{Cys}_{7}$, followed by an alpha-helix in amino acids $\mathrm{Val}_{8}$ $\operatorname{Arg}_{18}$ (Breeze et al., 1991). The next domain at residues 19-27 forms a hinge region (Conner et al., 2002). The C-terminus lies at residues 28-37, and contains two turn regions which form a putative binding epitope (Carpenter et al., 2001). It appears that the $\mathrm{N}$-terminal cyclic portion of the CGRP molecule, containing a ring structure with a disulfide bond, is essential for agonistic activity (Maggi et al., 1990). It is interesting to note that the C-terminal fragment, $\mathrm{CGRP}_{8-37}$, is devoid of any agonist activity at CGRP receptors, although it behaves as a competitive antagonist against the intact peptide (Chiba et al., 1989).

Calcitonin gene-related peptide is widely distributed in the central and peripheral nervous systems, primarily in sensory fibers that are closely associated with blood vessels (Uddman et al., 1986). CGRP is often co-localized with other peptides in these fibers, especially the tachykinin substance P (Uddman et al., 1986). In the cerebral circulation, CGRP is released from sensory fibers originating in the trigeminal ganglia and acts to dilate cerebral vessels (McCulloch et al., 1986). In the gut, CGRP is also released from spinal afferents, where it dilates mucosal blood vessels and may protect against the acidic environment (Holzer, 2000). CGRPcontaining fibers also innervate coronary arteries of the heart (Gulbenkian et al., 1993).

The regulation of CGRP production is poorly understood. At a cellular level, nerve growth factor (NGF) up-regulates CGRP via the Ras/Raf/mitogen-activated protein kinase kinase-1 (MEK1)/p42/p44 pathway (Freeland et al., 2000).

In the human circulation, CGRP has a half-life of approximately 7-10 min (Kraenzlin et al., 1985; Struthers et al., 1986). Regarding its metabolism, it seems that there is not an obvious mechanism, and it is probably broken down via a number of routes. First, mast cell tryptase has a potent effect in cleaving CGRP into inactive fragments, both in vivo and in vitro. More specifically, if both CGRP and substance P are released simultaneously, then CGRP could be inactivated by enzymes (tryptases), released by mast cells in response to substance $\mathrm{P}$. This mechanism has been demonstrated in skin (Brain and Williams, 1988, 1989). Second, a matrix metalloproteinase II has the ability to metabolize CGRP and remove its vasodilator activity (Fernandez-Patron et al., 2000). Third, Sams-Nielsen et al. (2001) have provided evidence that CGRP is taken back up into sensory nerve terminals after repolarization in vitro. Finally, in the CSF, aCGRP is degraded by an endopeptidase that cleaves the peptide at the $\operatorname{Leu}_{16}-\mathrm{Ser}_{17}$ bond (Le Greves et al., 1989). 


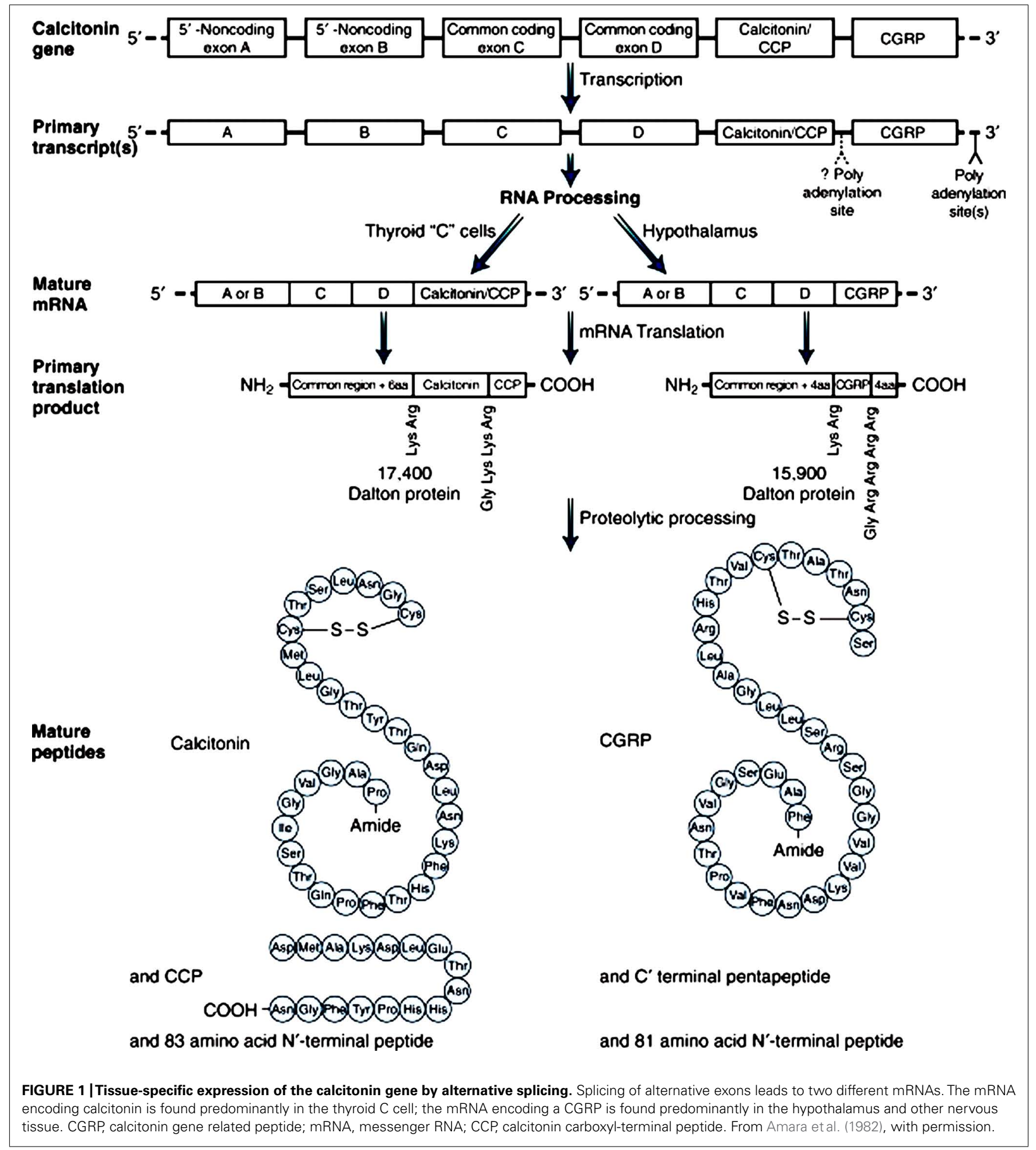

\section{STRUCTURE OF CGRP RECEPTORS}

Many peptides, including the CGRP family, mediate their actions via $\mathrm{G}$ protein-coupled receptors (GPCR). The GPCRs form the largest family of cell-surface proteins that are capable of interacting with an extracellular stimulus and transducing that stimulus to produce a reaction inside a cell (Pierce et al., 2002). All GPCRs have seven transmembrane spanning domains, an extracellular $\mathrm{N}$-terminus and an intracellular C-terminus and can be divided into three families based on signature amino acid sequences. Family A is the largest and generally binds small molecules and short peptides. Receptors in this class have been studied extensively, including photoreceptor rhodopsin, as well as adrenergic 
and olfactory receptors. Family B receptors bind larger peptides in the range of 27 to approximately 50 amino acids (secretin, glucagons, VIP, etc.). These receptors mediate the actions of CGRP and related peptides (Poyner et al., 2002; Hoare, 2005). Family $\mathrm{C}$ receptors include glutamate and $\mathrm{GABA}_{\mathrm{B}}$ receptors (Pierce et al., 2002).

Calcitonin receptor-like receptor (CLR), which belongs to family B of the GPCRs, comprises the main functional unit of the CGRP receptor (Figure 2). It was not until McLatchie's work (McLatchie et al., 1998) was published that it was recognized that a novel family of single transmembrane domain proteins, called receptor activity-membrane proteins (RAMP), were required to allow CLR to bind peptide and transduce signal. Three RAMPs have been identified so far $\left(\mathrm{RAMP}_{1}, \mathrm{RAMP}_{2}\right.$, and $\left.\mathrm{RAMP}_{3}\right)$. Each RAMP has a single transmembrane-spanning domain, a short intracellular C-terminal tail ( $\sim 9$ amino acids) and a long extracellular-terminus ( 100 amino acids; McLatchie et al., 1998). As a result of CLR and calcitonin receptor (CTR) interactions with RAMP, the International Union of Pharmacology (IUPHAR) nomenclature recognizes that CGRP interacts with CLR/RAMP $\left(\mathrm{CGRP}_{1}\right)$ receptors, whereas $\mathrm{AM}$ interacts with $\mathrm{CLR} / \mathrm{RAMP} \mathrm{P}_{2}$ $\left(\mathrm{AM}_{1}\right)$ or CLR/RAMP $3\left(\mathrm{AM}_{2}\right)$ receptors. The CTR without RAMP is sufficient for calcitonin binding, but CTR with RAMP 1, 2, or 3 are $\mathrm{AMY}_{1}, \mathrm{AMY}_{2}$, and $\mathrm{AMY}_{3}$ receptors, respectively (Poyner et al., 2002). The discovery of RAMPs has led to evolution of our understanding of how receptor diversity is implemented, providing a novel mechanism for generating receptor subtypes within a subset of family B GPCRs (Sexton et al., 2006).

The primary function of CLR is thought to be related to ligand binding, whereas the RAMP molecule plays a crucial role in receptor trafficking to the membrane and determination of receptor pharmacology. The RAMP family regulate the glycosylation and transport of the CLR. However, they are not CGRP receptors by themselves (McLatchie et al., 1998; Sexton et al., 2009). Terminal glycosylation of the receptor and transit from the endoplasmic reticulum/Golgi apparatus to the cell surface require interaction of CLR with RAMP (Sexton et al., 2009).

Calcitonin gene-related peptide receptor activation is known to involve several crucial elements, in common with other GPCRs, such as the presence of a proline "kink" in transmembrane helix (TM)6 (Conner et al., 2005), and a putative 'DRY' motif equivalent (Conner et al., 2007), similar to family A GPCRs. There is also evidence suggesting stabilization of the CLR interaction with $G$ "alpha" s $\left(\mathrm{Ga}_{\mathrm{s}}\right)$ by another $17 \mathrm{kDa}$ intracellular membrane protein, called RCP (Evans et al., 2000).

The existence of two receptors, $\mathrm{CGRP}_{1}$ and $\mathrm{CGRP}_{2}$, was originally proposed in the late 1980 s, with the $\mathrm{CGRP}_{1}$ receptor being the predominant mediator of cardiovascular effects. This receptor classification was developed as a consequence of pharmacological studies carried out with different agonists and antagonists in a range of tissue preparations, especially the positive inotropic effect in the guinea pig or rat atrium for determination of CGRP receptor activity, and the inhibition of electrically evoked twitch responses in the rat vas deferens for determination of $\mathrm{CGRP}_{2}$ receptor activity (Dennis et al., 1989, 1990; Dumont et al., 1997). In general, receptors that can be antagonized by the 30 -amino acid fragment of CGRP, $\mathrm{CGRP}_{8-37}$, with an approximate $\mathrm{pA}_{2}$ value of 7.0 are designated as $\mathrm{CGRP}_{1}$ receptors, while those that $\mathrm{CGRP}_{8-37}$ block with a $\mathrm{pA}_{2}$ of 6.0 or less are classified as $\mathrm{CGRP}_{2}$ receptors (Quirion et al., 1992; Poyner, 1995). However, it is questionable whether the $\mathrm{CGRP}_{2}$ receptor is a single receptor type or whether it is, in fact, explained by multiple molecular entities (Hay, 2007).

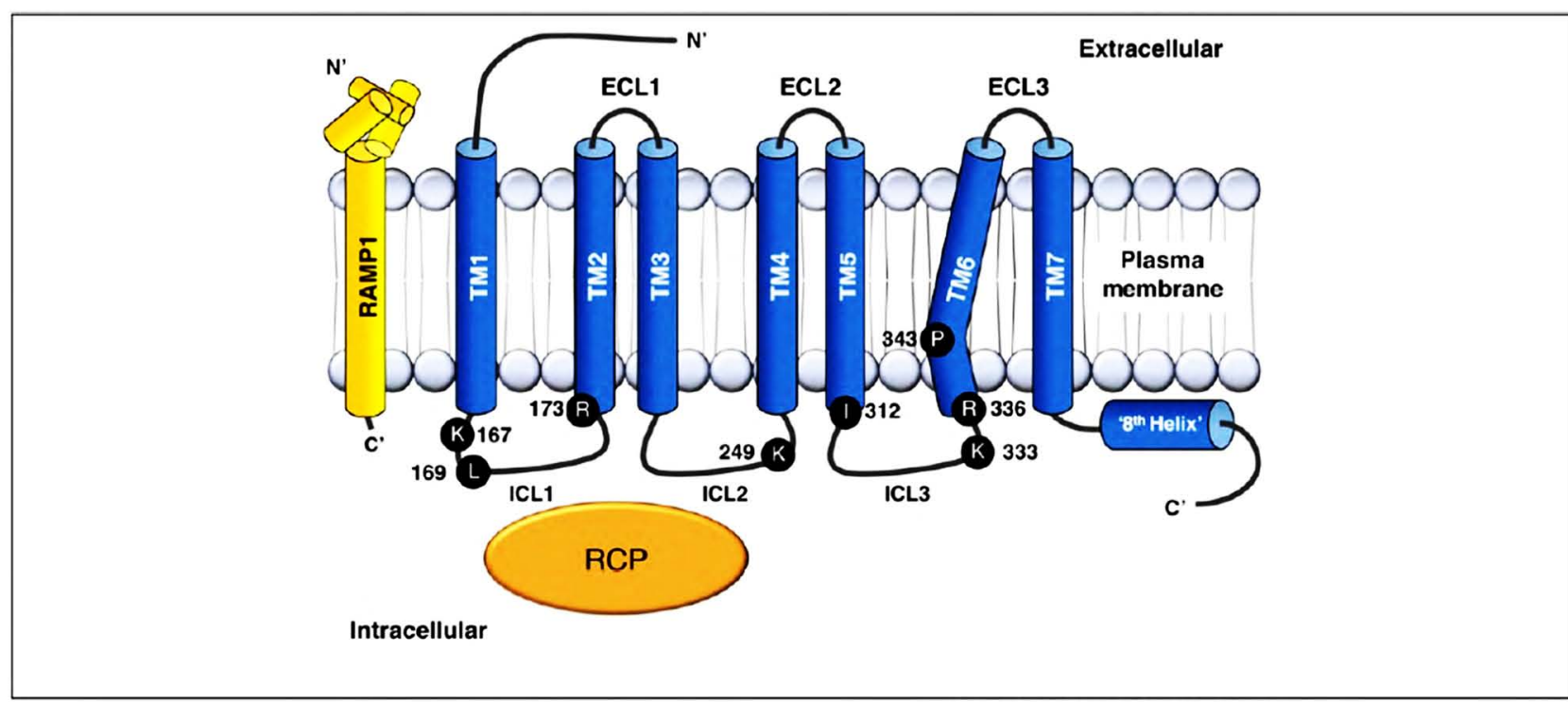

FIGURE 2 | Structure of CGRP receptor. CGRP receptor components and important residues for receptor signaling and internalization. The CGRP receptor is formed by CLR (blue), RAMP1 (yellow), and RCP (orange). Functionally important residues are shown as single letter abbreviations.
CGRP, calcitonin gene-related peptide: CLR, calcitonin receptor-like receptor; RAMP, receptor activity-modifying protein; $\mathrm{RCP}$, receptor component protein; $C^{\prime}$, C-terminal; EC, extracellular loop; ICL, intracellular loop; $\mathrm{N}^{\prime}, \mathrm{N}$-terminal; TM, transmembrane. From Walker et al. (2010), with permission. 
In contrast, $\mathrm{CGRP}_{1}$ is a well-defined receptor type consisting of CLR and RAMP 1 .

\section{SIGNAL TRANSDUCTION OF CGRP RECEPTOR}

Several mechanisms involved in CGRP-mediated vasorelaxation have been identified. These mechanisms include either NO-dependent endothelium-dependent mechanisms or cAMPmediated endothelium-independent pathways. The most common pathway is NO- and endothelium-independent. Activation of the CGRP receptor is generally accepted to result in $\mathrm{Ga}_{\mathrm{s}}$-mediated activation of adenylate cyclase, with a subsequent increase in cAMP and activation of protein kinase A (PKA). In the absence of endothelium, CGRP is able to cause relaxation, suggesting it must directly act on the smooth muscle cells to stimulate adenylate cyclase (Edvinsson et al., 1985, 1998; Crossman et al., 1990). The resulting rise in cAMP then activates PKA, which phosphorylates and opens up ATP-sensitive $\mathrm{K}^{+}$channels, thus leading to relaxation (Figure 3A; Nelson et al., 1990).

Endothelium-independent relaxation to CGRP occurs in the majority of tissues examined to date. Exceptions include the rat aorta, where the relaxation to CGRP occurs only in the presence of an intact endothelium and is attenuated by inhibitors of NO synthase, implying an NO-dependent mechanism (Brain et al., 1985; Gray and Marshall, 1992a,b). A significant increase in both cAMP and cGMP occurs and is also dependent on the presence of endothelium (Gray and Marshall, 1992a). This implicates the release of NO from the endothelium, which then relaxes the smooth muscle cells through activation of guanylate cyclase and accumulation of cGMP. Moreover, it has been shown that cAMP is able to stimulate eNOS activity, leading to increased synthesis and release of NO (Ferro et al., 1999; Queen et al., 2000). The activation of eNOS via cAMP is probably mediated via PKA, as a study demonstrated that various protein kinases can phosphorylate and activate eNOS (Butt et al., 2000). It is a possibility that CGRP causes an increase in cAMP in endothelial cells, which leads to PKA activation. PKA, in turn, activates eNOS, which results in NO release, and thus relaxation of the smooth muscle (Figure 3A).

There is some evidence for $\mathrm{Ga}_{\mathrm{i} / \mathrm{o}}$ signaling by the CGRP receptor, which is traditionally identified by sensitivity to pertussis toxin (PTX; Figure 3B). The CGRP-mediated stimulation of $\mathrm{Ca}^{2+}$ transients in rat nodose neurons and the activation of $\mathrm{c}$-Jun $\mathrm{N}$-terminal kinase (JNK) in SK-N-MC cells (which express endogenous CGRP receptors) both displayed PTX sensitivity (Wiley et al., 1992; Disa et al., 2000).

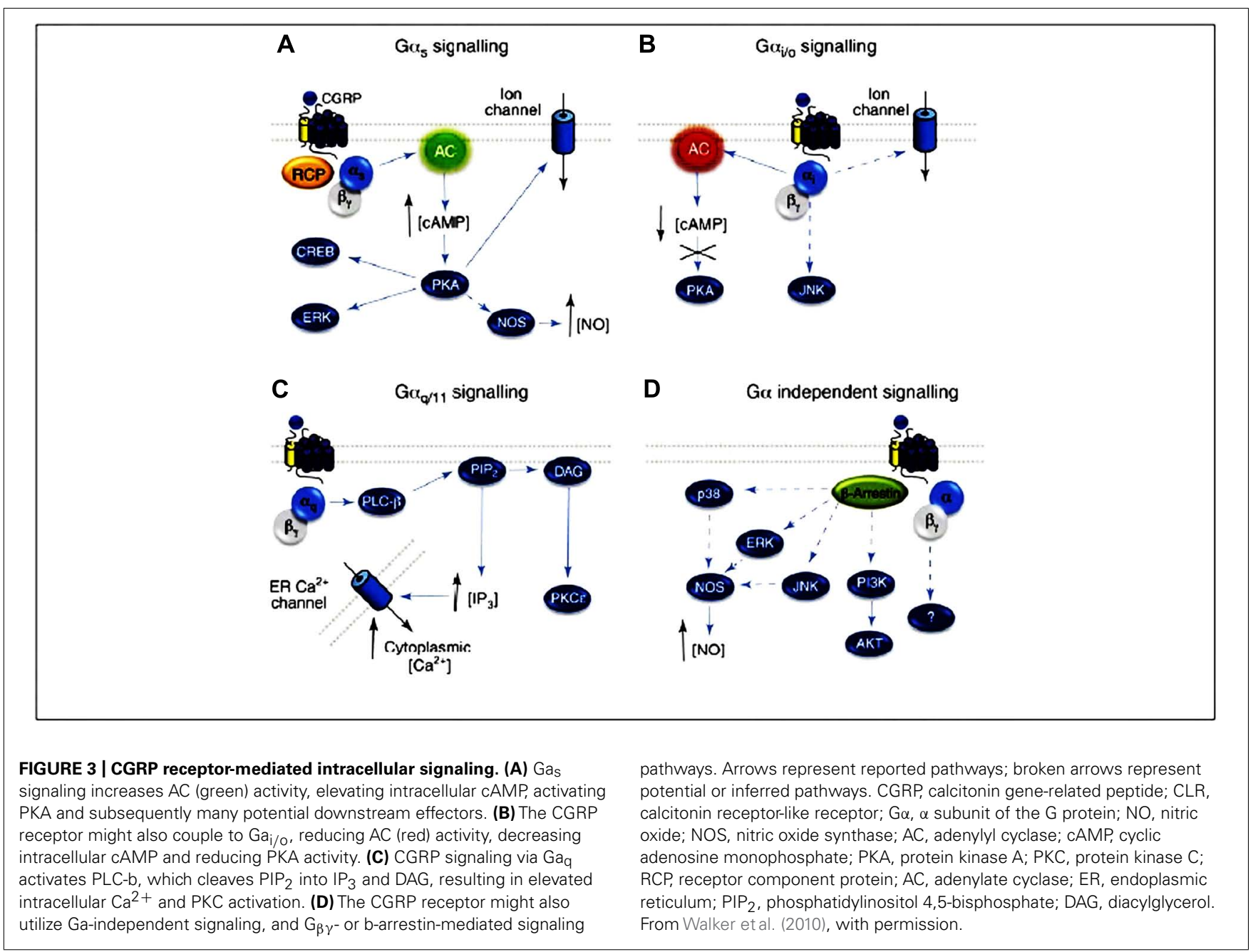


The CGRP receptor may also be able to stimulate intracellular activity through a different G protein. Aiyar et al. (1999) reported that CGRP was able to activate phospholipase C (PLC) in HEK293 cells, leading to an increase in intracellular $\mathrm{Ca}^{2+}$ via inositol trisphosphate (IP3) activity. This increase in $\mathrm{Ca}^{2+}$ occurred concurrently with the stimulation of adenylyl cyclase and accumulation of cAMP. Activation of PLC is considered to occur through $\mathrm{G}_{\mathrm{q} / 11 \alpha}$, rather than through $G \alpha_{s}$, suggesting that the activated CGRP receptor is able to interact with both types of $G$ protein. If this mechanism is present in endothelial cells, it provides an alternative explanation for CGRP activation of eNOS (which is traditionally considered to be dependent on $\mathrm{Ca}^{2+} /$ calmodulin for activation), independently of cAMP accumulation. The possibility that CGRP receptors may be coupled to phosphatidylinositol turnover is supported by another study that found this secondary messenger pathway in skeletal muscle (Laufer and Changeux, 1989; Figure 3C).

Recently, Meens et al. (2012) reported that activated CGRP receptors induce cyclic nucleotide-independent relaxation of vascular smooth muscle cells in mesenteric resistance arteries and terminate arterial effects of ET- 1 via $\mathrm{G}_{\beta \gamma}$. More specifically, CGRP receptor activation causes CAMP production but the relaxation of rat mesenteric resistance arteries induced by activation of this receptor involves $G_{\beta \gamma}$ and is not dependent on cAMP (Figure 3D).

Another study by Meens et al. (2010) discovered that CGRP released from peri-arterial sensory motor nerves terminates longlasting vasoconstrictor effects of ET-1 by promoting dissociation of ET-1/ET $\mathrm{A}_{\mathrm{A}}$-receptor complexes.

The CGRP receptor can also potentially activate other downstream signaling molecules, such as PKC and mitogen-activated protein kinase (MAPK) cascades, such as p38, JNK, and extracellular receptor activated kinase $1 / 2$ (ERK 1/2; Walker et al., 2010). CGRP receptor signaling is regulated by desensitization, internalization, and trafficking, which, as with other GPCRs, involves GPCR kinases (GRK), $\beta$ arrestin, and clathrin- and dynamindependent endocytosis (Walker et al., 2010). Padilla et al. (2007) proposed a mechanism by which endosomal endothelin converting enzyme-1 (ECE-1) degrades CGRP in endosomes to disrupt the peptide/receptor/ $\beta$-arrestin complex, freeing internalized receptors from $\beta$-arrestins and promoting recycling and resensitization, resulting in long-lasting vascular relaxing response to CGRP.

\section{CALCITONIN GENE-RELATED PEPTIDE AND SAH PRELIMINARY OBSERVATIONAL STUDIES}

An animal study of experimental SAH in rats revealed that the sensory innervation of the cerebral circulation by CGRP-containing fibers appeared to be reduced after SAH (estimated by the number of fibers present), and there was also a larger vasodilating response to CGRP in basilar arteries after SAH as compared to vessels from control animals. The reduction in CGRP could be due to release of the transmitter from the perivascular nerve terminals caused by blood in the subarachnoid space (Edvinsson et al., 1990).

In another study (Edvinsson et al., 1991), the proximal parts of the middle cerebral artery (MCA) were collected within $24 \mathrm{~h}$ after death from five humans suffering SAH (5-10 days beforehand) and from six subjects dying from myocardial infarction. In humans who had died from SAH the level of CGRP was nearly not detectable, being in contrast to that seen in age and sex matched subjects who had died of myocardial infarction. The trigeminocerebrovascular system was suggested by the authors to act as an anti-vasoconstrictor system by releasing stored peptides, CGRP being the most likely candidate.

Juul et al. (1995) measured CGRP levels with specific radioimmunoassays (RIA) in patients with $\mathrm{SAH}$, after operation with aneurysm clipping and nimodipine treatment. They used samples taken either from the external jugular vein $(n=20)$ or from the CSF $(n=14)$ during the postoperative course. They also used samples from healthy volunteers. The degree of vasoconstriction in the patients was monitored with Doppler ultrasound recordings. CGRP concentrations from the external jugular vein were significantly higher than from controls. Also, the CGRP level was measurable in SAH CSF but not in CSF of controls.

Others (Tran Dinh et al., 1994) showed that the basal level of endogenous CGRP in CSF was $0.77 \mathrm{nmol} / \mathrm{L}$ in rabbits. The CGRP concentration peaked at $14 \mathrm{nmol} / \mathrm{L}$ within $30 \mathrm{~min}$, and at $8 \mathrm{nmol} / \mathrm{L}$ within $24 \mathrm{~h}$, after SAH. They further showed that 3 days after SAH the CGRP concentration in CSF declined to $3.5 \mathrm{nmol} / \mathrm{L}$.

Nozaki et al. (1989a) produced a model of SAH by a single injection of fresh autologous arterial blood into the cisterna magna of dogs. Then, they examined changes of CGRP immunoreactivity immunohistochemically in perivascular nerve fibers of the large pial arteries. CGRP in cerebrovascular nerve fibers was suppressed after SAH. The suppression was first detected on the third day after $\mathrm{SAH}$, and was most marked during the 7th to 14th day. CGRP, however, recovered to a normal level by the 42 nd day after SAH.

Arienta et al. (1991) isolated the basilar artery from five rabbits subjected to SAH and five control animals. A mild or severe vasospasm was observed in the basilar artery about 15 min after injection of blood in the cisterna magna, while fluorescence immunohistochemistry revealed a marked decrease of the perivascular nerves containing CGRP in the animals of the experimental group, as compared to the control group.

\section{EFFECTS OF CGRP ADMINISTRATION ON CEREBRAL VASOSPASM AFTER EXPERIMENTAL SAH IN ANIMALS (Table 1)}

Nozaki et al. (1989b) produced experimental SAH in 30 dogs by injecting autologous arterial blood into the cisterna magna. They used two models of injection: in the first, single-injection model, $1 \mathrm{ml} / \mathrm{kg}$ of blood was injected on day 0 , while $0.5 \mathrm{ml} / \mathrm{kg}$ of blood was injected successively $48 \mathrm{~h}$ apart in the second, double-injection model, on day 0 and day 2. The diameter of the basilar artery was measured by angiography. The most marked constriction of the basilar artery was seen on day 3 after SAH in the singleinjection model and on day 7 in the double-injection model. When $10^{-10} \mathrm{~mol} / \mathrm{kg}$ of CGRP was administered intracisternally (i.c.) on day 3 in the single-injection model, cerebral vasospasm reversed completely. The effect began to appear 5 min after CGRP administration, continued for $4 \mathrm{~h}$, and disappeared by $24 \mathrm{~h}$ after the administration. When CGRP was administered at doses of $10^{-11}$ to $2 \times 10^{-10} \mathrm{~mol} / \mathrm{kg}$ on day 7 after $\mathrm{SAH}$ in the double-injection model, the cerebral vasospasm was reversed in a dose-dependent manner: $2 \times 10^{-10} \mathrm{~mol} / \mathrm{kg}$ of CGRP reversed the vasospasm completely. The effect began to appear $5 \mathrm{~min}$ after the CGRP 
Table 1 | Studies of CGRP administration after experimental SAH in animals.

\begin{tabular}{|c|c|c|c|c|c|c|}
\hline Reference & $\begin{array}{l}\text { Animal } \\
\text { model }\end{array}$ & $\begin{array}{l}\text { Total sample size } \\
\text { (intervention/ } \\
\text { control) }\end{array}$ & $\begin{array}{l}\text { Way of CGRP } \\
\text { administration }\end{array}$ & CGRP dose & Results & Adverse events \\
\hline Nozaki et al. (1989b) & Dog & $30(22 / 8)$ & i.c. & $2 \times 10^{-10} \mathrm{~mol} / \mathrm{kg}$ & $\begin{array}{l}\text { Vasospasm was reversed } \\
\text { completely }\end{array}$ & $\begin{array}{l}\text { AP and HR slightly } \\
\text { increased }\end{array}$ \\
\hline Imaizumi et al. (1996) & Rabbit & $16(8 / 8)$ & i.c. & $10^{-10} \mathrm{~mol} / \mathrm{kg}$ & $\begin{array}{l}\text { Basilar artery dilated from } 73 \text { to } \\
117 \% \text {, significantly larger than } \\
67 \% \text { in control }(p<0.01)\end{array}$ & None \\
\hline Toshima et al. (1992) & Rabbit & $41(17 / 24)$ & i.c./i.v. & $\begin{array}{l}100 \text { ng/kg/min i.c./ } \\
100 \text { ng/kg/min i.v. }\end{array}$ & $\begin{array}{l}\text { Basilar artery diameter in either } \\
\text { i.v. or i.c. CGRP groups was } \\
\text { significantly greater than that of } \\
\text { the respective control group }\end{array}$ & $\begin{array}{l}\text { AP drop in i.v. CGRP } \\
\text { administration }\end{array}$ \\
\hline Ahmad et al. (1996) & Rabbit & $45(22 / 23)$ & $\begin{array}{l}\text { i.c. slow-release } \\
\text { tablet }\end{array}$ & 24 or $153 \mu \mathrm{g}$ & $\begin{array}{l}\text { Vasospasm was completely } \\
\text { reversed }\end{array}$ & None \\
\hline Inoue et al. (1996) & Monkey & $10(5 / 5)$ & $\begin{array}{l}\text { i.c. slow-release } \\
\text { tablet }\end{array}$ & $1,200 \mu \mathrm{g}$ & $\begin{array}{l}\text { Cerebral vasospasm was } \\
\text { significantly ameliorated }\end{array}$ & None \\
\hline Toyoda et al. (2000) & Rabbit & $16(8 / 8)$ & $\begin{array}{l}\text { i.c. adenovirus- } \\
\text { mediated CGRP } \\
\text { gene transfer }\end{array}$ & NA & $\begin{array}{l}\text { Arterial diameter was similar } \\
\text { before and after SAH in CGRP } \\
\text { group }\end{array}$ & None \\
\hline Satoh et al. (2002) & Dog & $20(8 / 12)$ & $\begin{array}{l}\text { i.c. adenovirus- } \\
\text { mediated CGRP } \\
\text { gene transfer }\end{array}$ & NA & $\begin{array}{l}\text { Vasospasm was significantly } \\
\text { reduced compared with the } \\
\text { control group }\end{array}$ & None \\
\hline
\end{tabular}

i.c., intra-cisternal; i.v., intravenous; AP, arterial pressure; HR, heart rate; SAH, subarachnoid hemorrhage; NA, non-applicable.

administration, continued for $4 \mathrm{~h}$, and disappeared by $24 \mathrm{~h}$. Of note, when the amounts of CGRP mentioned above were administered i.c., both mean arterial blood pressure and heart rate were only slightly increased and returned to the previous levels within several minutes.

In a similar study by Imaizumi et al. (1996), experimental SAH was produced by i.c. injection of arterial blood in rabbits. The animals were treated with intrathecal administration of CGRP 3 days after SAH. The degree of vasospasm and the effect of CGRP were evaluated angiographically by measuring the basilar artery diameter. The basilar artery constricted to $73 \%$ of the pre-SAH values 3 days after SAH. Fifteen minutes after $10^{-10} \mathrm{~mol} / \mathrm{kg}$ CGRP injection, the basilar artery dilated from 73 to $117 \%(n=8)$, which was significantly larger than $67.1 \%$ in the vehicle group $(n=8 ; p<0.01)$. At $6 \mathrm{~h}$ after $10^{-10} \mathrm{~mol} / \mathrm{kg}$ CGRP injection, the basilar artery was still dilated to $90 \%(p<0.05)$. In the $10^{-11} \mathrm{~mol} / \mathrm{kg}$ CGRP group, the basilar artery was dilated to $87 \%(p<0.05) 15 \mathrm{~min}$ after the injection. The injection of $10^{-12} \mathrm{~mol} / \mathrm{kg}$ CGRP had no significant effect. The dilatory effect in the $10^{-10} \mathrm{~mol} / \mathrm{kg}$ CGRP group was demonstrated up to $6 \mathrm{~h}$ after injection. Arterial blood pressure was stable after injection of CGRP.

Toshima et al. (1992) produced SAH in 41 rabbits by injecting i.c. autologous blood. The animals were randomly assigned to five groups and were sacrificed on day 2 post-SAH. Group 1 was the control group. Immediately prior to sacrifice, group 2 and 3 animals received a 2-h i.c. injection of vehicle or CGRP (100 ng/kg/min), respectively. Group 4 and 5 animals received a 2-h i.v. injection of vehicle or CGRP (100 ng/ $\mathrm{kg} / \mathrm{min})$, respectively. The diameter of basilar artery in group 3 (i.c. CGRP) was significantly larger than that in group 2 (i.c. vehicle, $p<0.001$ ). Similarly, the diameter of basilar artery in group 5 (i.v. CGRP) was significantly greater than that in group 4 (i.v. vehicle, $p<0.01$ ). Although no significant difference was observed in mean arterial blood pressure between groups 2 and 3 (i.c. groups), there was a significant difference between i.v. groups 4 and 5 (lower in group 5 , $p<0.01)$.

Ahmad et al. (1996) implanted a CGRP slow-release tablet i.c., containing either 24 or $153 \mu \mathrm{g}$ of human aCGRP, $24 \mathrm{~h}$ after experimental SAH was induced in rabbits. Following implantation, the CGRP level in the CSF remained elevated for 5 days. The implantation of the tablet almost completely ameliorated angiographic vasospasm. Moreover, no significant systemic hypotension or neurological adverse event was associated with the treatment.

In a similar approach, Inoue etal. (1996) investigated the efficacy of a CGRP slow-release tablet for the prevention of cerebral vasospasm after SAH in monkeys. Experimental SAH was produced by the method of Espinosa et al. (1984). The animal underwent a right frontotemporal craniectomy under sterile conditions. The dura mater was opened, and the arachnoid membrane was microsurgically incised until the ipsilateral internal carotid 


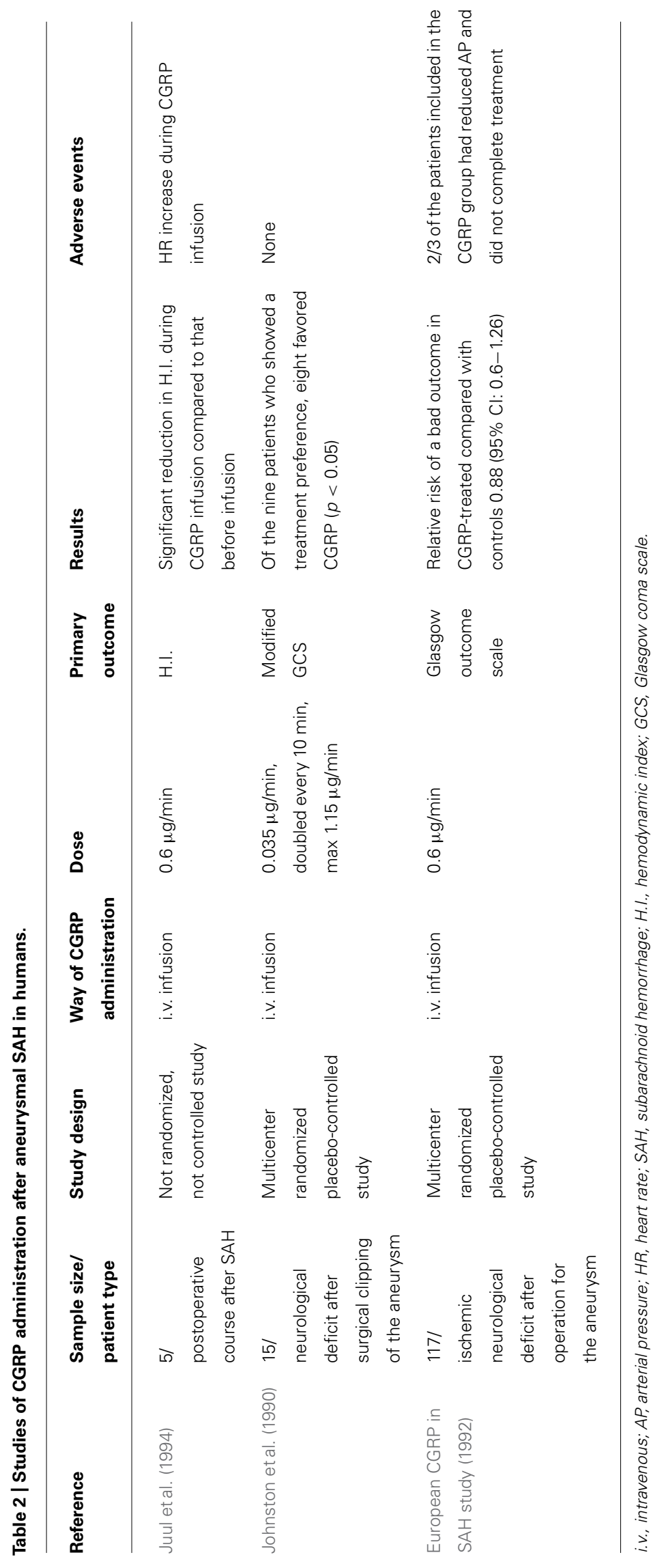


artery (ICA) and proximal portions of the MCA and anterior cerebral artery (ACA) were exposed. An autologous blood clot $(1 \mathrm{ml} / \mathrm{kg}$ ) was then placed around the exposed arteries to produce experimental SAH. For animals in the CGRP $(n=5)$ and placebo $(n=5)$ groups, a total of three tablets (total drug $1200 \mu \mathrm{g})$ were ipsilaterally placed under the frontal and temporal lobes at the time of SAH production. In the control group, cerebral vasospasm developed on day 7 (56\% as an average of the ICA, MCA, and ACA). In the CGRP group, vasospasm was significantly ameliorated on average $(75 \%, p<0.02)$. The CGRP concentration in CSF was measurable only on day 7 for the CGRP group $(6.5 \mathrm{nmol} / \mathrm{L})$. No significant untoward reactions were recorded.

Toyoda et al. (2000) sought to determine whether adenovirusmediated gene transfer in vivo of CGRP, ameliorates cerebral vasoconstriction after experimental SAH. Arterial blood was injected into the cisterna magna of rabbits to mimic SAH 5 days after injection of adenovirus or vehicle. After injection of adenovirus $(n=8)$, there was a 400 -fold increase in CGRP in CSF. In rabbits treated with vehicle (controls, $n=8$ ), basilar artery diameter after SAH was 25\% smaller than before SAH $(p<0.0005)$. In rabbits treated with adenovirus, arterial diameter was similar before and after SAH. Furthermore, treatment of rabbits with adenovirus after experimental SAH prevented spasm of the basilar artery 2 days after SAH.

Likewise, Satoh et al. (2002) investigated whether a delayed treatment with adenovirus encoding CGRP gene, 2 days after experimental SAH, reduces cerebral vasospasm in a doublehemorrhage model (on days 0 and 2 ) of severe vasospasm in dogs. Severe vasospasm was observed in control SAH dogs $(n=12)$ on day 7 , and the mean basilar artery diameter was $53 \%$ of baseline. In the group treated with adenovirus $(n=8)$, vasospasm was significantly reduced (the basilar artery diameter was $78 \%$ of baseline, $p<0.05$ compared with the control SAH group). High levels of CGRP were measured in CSF from dogs that received adenovirus (115-fold greater than baseline levels).

Intracisternal gene transfer of CGRP was initially thought to be more useful than i.v. infusion, because the local gene transfer might avoid systemic effects of CGRP and achieve its sustained release into the central nervous system. However, there are several concerns, such as the inflammatory process induced by adenovirus, the difficulty in approaching the target cells in the presence of a large subarachnoid blood clot, and its potential ability for cancerous transformation of the affected cells.

\section{EFFECTS OF CGRP ADMINISTRATION ON CEREBRAL VASOSPASM AFTER SAH IN HUMANS (Table 2)}

Juul et al. (1994) investigated the effect of i.v. CGRP infusion at a rate of $0.6 \mu \mathrm{g} / \mathrm{min}$ in five patients with vasoconstriction in the postoperative course after SAH, where the hemodynamic index (ratio between middle cerebral and ICA mean velocities) was used as an indicator of vasoconstriction. A significant reduction was found in the hemodynamic index during the CGRP infusion as compared to that before infusion ( 4.3 vs. 6.2, $p<0.05$ ). However, no significant change was observed in pulsatility index (another indicator of vasospasm, equal to the difference between the systolic and diastolic flow velocities divided by the mean flow velocity), blood pressure, or consciousness during CGRP infusion. A significant increase in heart rate was observed during the infusion, while blood pressure remained unaltered.

Johnston et al. (1990) undertook a multicenter, randomized, placebo-controlled trial to study the safety and efficacy of i.v. CGRP treatment to reverse neurological deficits after surgical clipping of a ruptured intracranial aneurysm. Patients were enrolled if they had postoperative neurological deficit. Patients received CGRP or placebo in random order, $24 \mathrm{~h}$ apart. Fifteen patients were eventually included in the study. Infusion started at a rate sufficient to deliver $0.035 \mu \mathrm{g} / \mathrm{min}$ CGRP, and was doubled every 10 min until either a clinical response was obtained or a maximum dose of $1.15 \mu \mathrm{g} / \mathrm{min}$ was reached at $1 \mathrm{~h}$. If the neurological deficit had not deteriorated and the patient had no side-effects by that time, the maximum infusion rate was continued for another $20 \mathrm{~min}$. Regarding neurological changes according to the modified Glasgow Coma Scale, five patients did not improve on either treatment, one improved on both, eight improved on CGRP but not on placebo, and one improved on placebo but not on CGRP. Of the nine patients who showed a treatment preference, eight (88.9\%) favored CGRP $(p<0.05)$. The mean duration of neurological improvement was $25 \mathrm{~min}$, after which patients returned to their previous neurological status. There was a significant decrease in both systolic and diastolic blood pressures during the infusion of CGRP.

A larger, multicenter, randomized controlled trial (European CGRP in SAH study, 1992) investigated the effect of a postoperative infusion of CGRP on outcome at 3 months. Patients with aneurysmal SAH who underwent surgery entered the trial if an ischemic neurological deficit developed after the operation. A total of 117 patients entered the study (62 patients received CGRP and 55 standard management). The CGRP-treated patients received the drug by i.v. infusion at a rate of $0.6 \mu \mathrm{g} / \mathrm{min}$. If systemic hypotension developed, the infusion rate was reduced to $0.45 \mu \mathrm{g} / \mathrm{min}$, then to $0.3 \mu \mathrm{g} / \mathrm{min}$, if the hypotension was still apparent. CGRP treatment was given for at least $4 \mathrm{~h}$; patients who showed a satisfactory neurological response continued to receive treatment for up to 10 days (minimum of 4 days). The percentage of patients with a good outcome was slightly but not significantly higher in the CGRP than in the control group. The relative risk of a bad outcome in CGRP-treated compared with control patients was 0.88 (95\% CI: $0.60-1.28)$. Interestingly, only a third of patients randomized to receive CGRP completed treatment, so two-thirds included in the treatment group for the analyses had limited exposure to CGRP, mainly due to arterial hypotension.

\section{CONCLUSION}

The pathogenesis of vasospasm after SAH is complex, multifactorial, and incompletely understood. CGRP has shown promising results both in vitro and in vivo, mainly in animal models of experimental SAH. However, there is a lack of studies in humans. Systemic hypotension induced by the i.v. administration of the drug seems to be a serious problem. The encouraging results from the i.c. application of CGRP in animals could warrant large studies in humans with CGRP instillation into the subarachnoid space, in order to avoid hypotension and achieve even more efficient dilatation of the cerebral arteries. 


\section{REFERENCES}

Ahmad, I., Imaizumi, S., Shimizu, H., Kaminuma, T., Ochiai, N., Tajima, M., et al. (1996). Development of calcitonin gene-related peptide slow-release tablet implanted in CSF space for prevention of cerebral vasospasm after experimental subarachnoid haemorrhage. Acta Neurochir. (Wien) 138, 1230-1240.

Aiyar, N., Disa, J., Stadel, J. M., and Lysko, P. G. (1999). Calcitonin gene-related peptide receptor independently stimulates $3^{\prime}, 5^{\prime}$-cyclic adenosine monophosphate and $\mathrm{Ca}^{2+}$ signaling pathways. Mol. Cell. Biochem. 197, 179-185.

Al-Tamimi, Y. Z., Orsi, N. M., Quinn, A. C., Homer-Vanniasinkam, S., and Ross, S. A. (2010). A review of delayed ischemic neurologic deficit following aneurysmal subarachnoid hemorrhage: historical overview, current treatment, and pathophysiology. World Neurosurg. 73, 654-667.

Alevizaki, M., Shiraishi, A., Rassool, F. V., Ferrier, G. J., MacIntyre, I., and Legon, S. (1986). The calcitoninlike sequence of the beta CGRP gene. FEBS Lett. 206, 47-52.

Amara, S. G., Jonas, V., Rosenfeld, M. G., Ong, E. S., and Evans, R. M. (1982). Alternative RNA processing in calcitonin gene expression generates mRNAs encoding different polypeptide products. Nature 298, 240-244.

Amin-Hanjani, S., Ogilvy, C. S., and Barker, F. G. (2004). Does intracisternal thrombolysis prevent vasospasm after aneurysmal subarachnoid hemorrhage? A meta-analysis. Neurosurgery 54, 326-334.

Arienta, C., Balbi, S., Caroli, M., and Fumagalli, G. (1991). Depletion of calcitonin gene-related peptide in perivascular nerves during acute phase of posthemorrhagic vasospasm in the rabbit. Brain Res. Bull. 27, 605-609.

Asano, T., and Matsui, T. (1999). Antioxidant therapy against cerebral vasospasm following aneurysmal subarachnoid hemorrhage. Cell Mol. Neurobiol. 19, 31-44.

Benarroch, E. E. (2011). CGRP: sensory neuropeptide with multiple neurologic implications. Neurology 77, 281-287.

Brain, S. D., and Williams, T. J. (1988). Substance P regulates the vasodilator activity of calcitonin gene-related peptide. Nature 335, 73-75.

Brain, S. D., and Williams, T. J. (1989). Interactions between the tachykinins and calcitonin gene-related peptide lead to the modulation of oedema formation and blood flow in rat skin. Br. J. Pharmacol. 97, 77-82.

Brain, S. D., Williams, T. J., Tippins, J. R., Morris, H. R., and MacIntyre, I. (1985). Calcitonin gene-related peptide is a potent vasodilator. Nature 313, 54-56.

Breeze, A. L., Harvey, T. S., Bazzo, R., and Campbell, I. D. (1991). Solution structure of human calcitonin gene-related peptide by $1 \mathrm{H}$ NMR and distance geometry with restrained molecular dynamics. Biochemistry 30, 575-582.

Brisman, J. L., Eskridge, J. M., and Newell, D. W. (2006). Neurointerventional treatment of vasospasm. Neurol. Res. 28, 769-776.

Butt, E., Bernhardt, M., Smolenski, A., Kotsonis, P., Frohlich, L. G., Sickmann, A., et al. (2000). Endothelial nitric-oxide synthase (type III) is activated and becomes calcium independent upon phosphorylation by cyclic nucleotide-dependent protein kinases. J. Biol. Chem. 275, 51795187.

Carpenter, K. A., Schmidt, R., von Mentzer, B., Haglund, U., Roberts, E. and Walpole, C. (2001). Turn structures in CGRP C-terminal analogues promote stable arrangements of key residue side chains. Biochemistry 40, 8317-8325.

Chiba, T., Yamaguchi, A., Yamatani, T., Nakamura, A., Morishita, T., Inui, T., et al. (1989). Calcitonin gene-related peptide receptor antagonist human CGRP-(8-37). Am. J. Physiol. 256, E331-E335.

Chow, M., Dumont, A. S., and Kassell, N. F. (2002). Endothelin receptor antagonists and cerebral vasospasm: an update. Neurosurgery 51, 1333 1341.

Clark, J. F., and Sharp, F. R. (2006). Bilirubin oxidation products (BOXes) and their role in cerebral vasospasm after subarachnoid hemorrhage. J. Cereb. Blood Flow Metab. 26, 1223-1233.

Conner, A. C., Hay, D. L., Howitt, S. G., Kilk, K., Langel, U., Wheatley, M., et al. (2002). Interaction of calcitonin-gene-related peptide with its receptors. Biochem. Soc. Trans. 30, 451-455.

Conner, A. C., Hay, D. L., Simms, J., Howitt, S. G., Schindler, M., Smith, D. M., et al. (2005). A key role for transmembrane prolines in calcitonin receptor-like receptor agonist binding and signalling: implications for family B G-protein-coupled receptors. Mol. Pharmacol. 67, 20-31.

Conner, A. C., Simms, J., Barwell, J., Wheatley, M., and Poyner, D. R.
(2007). Ligand binding and activation of the CGRP receptor. Biochem. Soc. Trans. 35, 729-732.

Crossman, D. C., Dashwood, M. R., Brain, S. D., McEwan, J., and Pearson, J. D. (1990). Action of calcitonin gene-related peptide upon bovine vascular endothelial and smooth muscle cells grown in isolation and co-culture. Br. J. Pharmacol. 99, 71-76.

Dennis, T., Fournier, A., Cadieux, A., Pomerleau, F., Jolicoeur, F. B., St Pierre, S., etal. (1990). hCGRP837, a calcitonin gene-related peptide antagonist revealing calcitonin gene-related peptide receptor heterogeneity in brain and periphery. $J$. Pharmacol. Exp. Ther. 254, 123-128.

Dennis, T., Fournier, A., St Pierre, S. and Quirion, R. (1989). Structureactivity profile of calcitonin generelated peptide in peripheral and brain tissues. Evidence for receptor multiplicity. J. Pharmacol. Exp. Ther. 251, 718-725.

Disa, J., Parameswaran, N., Nambi, P., and Aiyar, N. (2000). Involvement of cAMP-dependent protein kinase and pertussis toxin-sensitive G-proteins in CGRP mediated JNK activation in human neuroblastoma cell line. Neuropeptides 34, 229-233.

Dorhout Mees, S. M., Algra, A., Vandertop, W. P., van Kooten, F., Kuijsten, H. A., Boiten, J., et al. (2012). Magnesium for aneurysmal subarachnoid haemorrhage (MASH2): a randomised placebo-controlled trial. Lancet 380, 44-49.

Dorsch, N. W. (1995). Cerebral arterial spasm - a clinical review. $\mathrm{Br}$. $J$. Neurosurg. 9, 403-412.

Dreier, J. P., Major, S., Manning, A., Woitzik, J., Drenckhahn, C., Steinbrink, J., etal. (2009). Cortical spreading ischaemia is a novel process involved in ischaemic damage in patients with aneurysmal subarachnoid haemorrhage. Brain 132, 1866-1881.

Duerrschmidt, N., Wippich, N., Goettsch, W., Broemme, H. J., and Morawietz, H. (2000). Endothelin-1 induces $\mathrm{NAD}(\mathrm{P}) \mathrm{H}$ oxidase in human endothelial cells. Biochem. Biophys. Res. Commun. 269, 713-717.

Dumont, A. S., Dumont, R. J., Chow, M. M., Lin, C. L., Calisaneller, T., Ley, K. F., et al. (2003). Cerebral vasospasm after subarachnoid hemorrhage: putative role of inflammation. Neurosurgery 53, 123-133.

Dumont, Y., Fournier, A., St-Pierre, S., and Quirion, R. (1997). A potent and selective CGRP2 agonist, [Cys(Et)2,7]hCGRP alpha: comparison in prototypical CGRP1 and
CGRP2 in vitro bioassays. Can. J Physiol. Pharmacol. 75, 671-676.

Edvinsson, L., Delgado-Zygmunt, T., Ekman, R., Jansen, I., Svendgaard, N. A., and Uddman, R. (1990). Involvement of perivascular sensory fibers in the pathophysiology of cerebral vasospasm following subarachnoid hemorrhage. J. Cereb. Blood Flow Metab. 10, 602-607.

Edvinsson, L., Ekman, R., Jansen, I., McCulloch, J., Mortensen, A., and Uddman, R. (1991). Reduced levels of calcitonin gene-related peptide-like immunoreactivity in human brain vessels after subarachnoid haemorrhage. Neurosci. Lett. 121, 151-154.

Edvinsson, L., Fredholm, B. B., Hamel, E., Jansen, I., and Verrecchia, C. (1985). Perivascular peptides relax cerebral arteries concomitant with stimulation of cyclic adenosine monophosphate accumulation or release of an endothelium-derived relaxing factor in the cat. Neurosci. Lett. 58, 213-217.

Edvinsson, L., Gulbenkian, S., Barroso, C. P., Cunha e Sa, M., Polak, J. M., Mortensen, A., et al. (1998). Innervation of the human middle meningeal artery: immunohistochemistry, ultrastructure, and role of endothelium for vasomotility. Peptides 19, 1213-1225.

Egge, A., Waterloo, K., Sjoholm, H., Solberg, T., Ingebrigtsen, T., and Romner, B. (2001). Prophylactic hyperdynamic postoperative fluid therapy after aneurysmal subarachnoid hemorrhage: a clinical, prospective, randomized, controlled study. Neurosurgery 49, 593-605.

Espinosa, F., Weir, B., Overton, T., Castor, W., Grace, M., and Boisvert, D. (1984). A randomized placebo-controlled double-blind trial of nimodipine after SAH in monkeys. Part 1: clinical and radiological findings. J. Neurosurg. 60, 1167-1175.

European CGRP in Subarachnoid Haemorrhage Study Group. (1992). Effect of calcitonin-gene-related peptide in patients with delayed postoperative cerebral ischaemia after aneurysmal subarachnoid haemorrhage. European CGRP in Subarachnoid Haemorrhage Study Group. Lancet 339, 831-834.

Evans, B. N., Rosenblatt, M. I., Mnayer, L. O., Oliver, K. R., and Dickerson, I. M. (2000). CGRP-RCP, a novel protein required for signal transduction at calcitonin gene-related peptide and adrenomedullin receptors. J. Biol. Chem. 275, 31438-31443.

Fassbender, K., Hodapp, B., Rossol, S., Bertsch, T., Schmeck, J., Schutt, S., 
et al. (2001). Inflammatory cytokines in subarachnoid haemorrhage: association with abnormal blood flow velocities in basal cerebral arteries. J. Neurol. Neurosurg. Psychiatry 70, 534-537.

Fassbender, K., Hodapp, B., Rossol, S., Bertsch, T., Schmeck, J., Schutt, S., etal. (2000). Endothelin-1 in subarachnoid hemorrhage: an acutephase reactant produced by cerebrospinal fluid leukocytes. Stroke 31, 2971-2975.

Fernandez-Patron, C., Stewart, K. G., Zhang, Y., Koivunen, E., Radomski, M. W., and Davidge, S. T. (2000). Vascular matrix metalloproteinase2-dependent cleavage of calcitonin gene-related peptide promotes vasoconstriction. Circ. Res. 87, 670-676.

Ferro, A., Queen, L. R., Priest, R. M., Xu, B., Ritter, J. M., Poston, L., et al. (1999). Activation of nitric oxide synthase by beta 2 -adrenoceptors in human umbilical vein endothelium in vitro. Br. J. Pharmacol. 126, 1872 1880.

Freeland, K., Liu, Y. Z., and Latchman, D. S. (2000). Distinct signalling pathways mediate the cAMP response element (CRE)-dependent activation of the calcitonin gene-related peptide gene promoter by cAMP and nerve growth factor. Biochem. J. 345(Pt 2), 233-238.

Frontera, J. A., Fernandez, A., Schmidt, J. M., Claassen, J., Wartenberg, K. E., Badjatia, N., et al. (2009). Defining vasospasm after subarachnoid hemorrhage: what is the most clinically relevant definition? Stroke 40, 1963 1968.

Goretski, J., and Hollocher, T. C. (1988). Trapping of nitric oxide produced during denitrification by extracellular hemoglobin. J. Biol. Chem. 263, 2316-2323.

Gray, D. W., and Marshall, I. (1992a). Human alpha-calcitonin generelated peptide stimulates adenylate cyclase and guanylate cyclase and relaxes rat thoracic aorta by releasing nitric oxide. Br. J. Pharmacol. 107, 691-696.

Gray, D. W., and Marshall, I. (1992b). Nitric oxide synthesis inhibitors attenuate calcitonin gene-related peptide endothelium-dependent vasorelaxation in rat aorta. Eur. J. Pharmacol. 212, 37-42.

Grisham, M. B., Granger, D. N., and Lefer, D. J. (1998). Modulation of leukocyte-endothelial interactions by reactive metabolites of oxygen and nitrogen: relevance to ischemic heart disease. Free Radic. Biol. Med. 25, 404-433.
Gulbenkian, S., Saetrum, O. O., Ekman, R., Costa, A. N., Wharton, J., Polak, J. M., et al. (1993). Peptidergic innervation of human epicardial coronary arteries. Circ. Res. 73, 579-588.

Haley, E. C. Jr., Kassell, N. F., AppersonHansen, C., Maile, M. H., and Alves, W. M. (1997). A randomized, double-blind, vehicle-controlled trial of tirilazad mesylate in patients with aneurysmal subarachnoid hemorrhage: a cooperative study in North America. J. Neurosurg. 86, 467-474.

Hay, D. L. (2007). What makes a CGRP2 receptor? Clin. Exp. Pharmacol. Physiol. 34, 963-971.

Hino, A., Tokuyama, Y., Weir, B., Takeda, J., Yano, H., Bell, G. I., et al. (1996). Changes in endothelial nitric oxide synthase mRNA during vasospasm after subarachnoid hemorrhage in monkeys. Neurosurgery 39, 562-567.

Hirashima, Y., Nakamura, S., Endo, S., Kuwayama, N., Naruse, Y., and Takaku, A. (1997). Elevation of platelet activating factor, inflammatory cytokines, and coagulation factors in the internal jugular vein of patients with subarachnoid hemorrhage. Neurochem. Res. 22, 12491255.

Hoare, S. R. (2005). Mechanisms of peptide and nonpeptide ligand binding to Class B G-protein-coupled receptors. Drug Discov. Today 10, 417-427.

Holzer, P. (2000). Local microcirculatory reflexes and afferent signalling in response to gastric acid challenge. Gut 47(Suppl. 4), iv46-iv48.

Horowitz, A., Menice, C. B., Laporte, R., and Morgan, K. G. (1996). Mechanisms of smooth muscle contraction. Physiol. Rev. 76, 967-1003.

Huang, J., and van Gelder, J. M. (2002). The probability of sudden death from rupture of intracranial aneurysms: a meta-analysis. Neurosurgery 51, 1101-1105.

Ignarro, L. J. (1990). Biosynthesis and metabolism of endothelium-derived nitric oxide. Annu. Rev. Pharmacol. Toxicol. 30, 535-560.

Imaizumi, S., Shimizu, H., Ahmad, I., Kaminuma, T., Tajima, M., and Yoshimoto, T. (1996). Effect of calcitonin gene-related peptide on delayed cerebral vasospasm after experimental subarachnoid hemorrhage in rabbits. Surg. Neurol. 46, 263-270.

Ingall, T., Asplund, K., Mahonen, M., and Bonita, R. (2000). A multinational comparison of subarachnoid hemorrhage epidemiology in the WHO MONICA stroke study. Stroke 31, 1054-1061.
Inoue, T., Shimizu, H., Kaminuma, T., Tajima, M., Watabe, K., and Yoshimoto, T. (1996). Prevention of cerebral vasospasm by calcitonin gene-related peptide slow-release tablet after subarachnoid hemorrhage in monkeys. Neurosurgery 39, 984-990.

Ishiguro, M., Murakami, K., Link, T., Zvarova, K., Tranmer, B. I., Morielli, A. D., et al. (2008). Acute and chronic effects of oxyhemoglobin on voltagedependent ion channels in cerebral arteries. Acta Neurochir. Suppl. 104, 99-102.

Ishiguro, M., Wellman, T. L., Honda, A., Russell, S. R., Tranmer, B. I., and Wellman, G. C. (2005). Emergence of a R-type $\mathrm{Ca}^{2+}$ channel ( $\mathrm{CaV} 2.3$ ) contributes to cerebral artery constriction after subarachnoid hemorrhage. Circ. Res. 96, 419-426.

Jestaedt, L., Pham, M., Bartsch, A. J., Kunze, E., Roosen, K., Solymosi, L., et al. (2008). The impact of balloon angioplasty on the evolution of vasospasm-related infarction after aneurysmal subarachnoid hemorrhage. Neurosurgery 62, 610-617.

Johnston, F. G., Bell, B. A., Robertson, I. J., Miller, J. D., Haliburn, C., O'Shaughnessy, D., et al. (1990). Effect of calcitonin-gene-related peptide on postoperative neurological deficits after subarachnoid haemorrhage. Lancet 335, 869-872.

Jung, C. S., Iuliano, B. A., Harvey-White, J., Espey, M. G., Oldfield, E. H., and Pluta, R. M. (2004). Association between cerebrospinal fluid levels of asymmetric dimethyl-L-arginine, an endogenous inhibitor of endothelial nitric oxide synthase, and cerebral vasospasm in a primate model of subarachnoid hemorrhage. J. Neurosurg. 101, 836-842.

Juul, R., Aakhus, S., Bjornstad, K., Gisvold, S. E., Brubakk, A. O. and Edvinsson, L. (1994). Calcitonin gene-related peptide (human alphaCGRP) counteracts vasoconstriction in human subarachnoid haemorrhage. Neurosci. Lett. 170, 67-70.

Juul, R., Edvinsson, L., Gisvold, S. E., Ekman, R., Brubakk, A. O. and Fredriksen, T. A. (1990). Calcitonin gene-related peptide-LI in subarachnoid haemorrhage in man. Signs of activation of the trigeminocerebrovascular system? Br. J. Neurosurg. 4, 171-179.

Juul, R., Hara, H., Gisvold, S. E., Brubakk, A. O., Fredriksen, T. A. Waldemar, G., et al. (1995). Alterations in perivascular dilatory neuropeptides (CGRP, SP, VIP) in the external jugular vein and in the cerebrospinal fluid following subarachnoid haemorrhage in man. Acta Neurochir. (Wien) 132, 32-41.

Juvela, S. (2000). Plasma endothelin concentrations after aneurysmal subarachnoid hemorrhage. J. Neurosurg. 92, 390-400.

Kassell, N. F., Peerless, S. J., Durward, Q. J., Beck, D. W., Drake, C. G., and Adams, H. P. (1982). Treatment of ischemic deficits from vasospasm with intravascular volume expansion and induced arterial hypertension. Neurosurgery 11, 337-343.

Kasuya, H., Onda, H., Sasahara, A., Takeshita, M., and Hori, T. (2005). Application of nicardipine prolonged-release implants: analysis of 97 consecutive patients with acute subarachnoid hemorrhage. Neurosurgery 56, 895-902.

Kim, Y. W., Lawson, M. F., and Hoh, B. L. (2012). Nonaneurysmal subarachnoid hemorrhage: an update. Curr. Atheroscler. Rep. 14, 328-334.

Koide, M., Nystoriak, M. A., Brayden, J. E., and Wellman, G. C. (2011). Impact of subarachnoid hemorrhage on local and global calcium signaling in cerebral artery myocytes. Acta Neurochir. Suppl. 110(Pt 1), 145-150.

Kosnik, E. J., and Hunt, W. E. (1976). Postoperative hypertension in the management of patients with intracranial arterial aneurysms. J. Neurosurg. 45, 148-154.

Kostron, H., Twerdy, K., and Grunert, V. (1988). The calcium entry blocker nimodipine improves the quality of life of patients operated on for cerebral aneurysms. A 5-year follow-up analysis. Neurochirurgia (Stuttg.) 31, 150-153.

Kraenzlin, M. E., Ch'ng, J. L., Mulderry, P. K., Ghatei, M. A., and Bloom, S. R. (1985). Infusion of a novel peptide, calcitonin gene-related peptide (CGRP) in man. Pharmacokinetics and effects on gastric acid secretion and on gastrointestinal hormones. Regul. Pept. 10, 189-197.

Kwan, A. L., Lin, C. L., Chang, C. Z., Winardi, D., Yen, C. P., Wu, S. C., etal. (2002). Oral administration of an inhibitor of endothelin-converting enzyme attenuates cerebral vasospasm following experimental subarachnoid haemorrhage in rabbits. Clin. Sci. (Lond.) 103(Suppl. 48), 414S-417S.

Laufer, R., and Changeux, J. P. (1989). Calcitonin gene-related peptide and cyclic AMP stimulate phosphoinositide turnover in skeletal muscle cells. Interaction between two second messenger systems. J. Biol. Chem. 264, 2683-2689. 
Le Greves, P., Nyberg, F., Hokfelt, T., and Terenius, L. (1989). Calcitonin gene-related peptide is metabolized by an endopeptidase hydrolyzing substance P. Regul. Pept. 25, 277-286.

Lennihan, L., Mayer, S. A., Fink, M. E., Beckford, A., Paik, M. C., Zhang, H., et al. (2000). Effect of hypervolemic therapy on cerebral blood flow after subarachnoid hemorrhage: a randomized controlled trial. Stroke 31, 383-391.

Lin, C. L., Hsu, Y. T., Lin, T. K., Morrow, J. D., Hsu, J. C., Hsu. Y. H., et al. (2006). Increased levels of F2-isoprostanes following aneurysmal subarachnoid hemorrhage in humans. Free Radic. Biol. Med. 40, 1466-1473.

Lynch, J. R., Wang, H., McGirt, M. J., Floyd, J., Friedman, A. H., Coon, A. L., et al. (2005). Simvastatin reduces vasospasm after aneurysmal subarachnoid hemorrhage: results of a pilot randomized clinical trial. Stroke 36, 2024-2026.

Macdonald, R. L., Higashida, R. T., Keller, E., Mayer, S. A., Molyneux, A., Raabe, A., et al. (2011). Clazosentan, an endothelin receptor antagonist, in patients with aneurysmal subarachnoid haemorrhage undergoing surgical clipping: a randomised, double-blind, placebo-controlled phase 3 trial (CONSCIOUS-2). Lancet Neurol. 10, 618-625.

Macdonald, R. L., Kassell, N. F., Mayer, S., Ruefenacht, D., Schmiedek, P., Weidauer, S., et al. (2008). Clazosentan to overcome neurological ischemia and infarction occurring after subarachnoid hemorrhage (CONSCIOUS-1): randomized, double-blind, placebo-controlled phase 2 dose-finding trial. Stroke 39, 3015-3021.

Macdonald, R. L., Weir, B. K., Runzer, T. D., Grace, M. G., Findlay, J. M., Saito, K., et al. (1991). Etiology of cerebral vasospasm in primates. J. Neurosurg. 75, 415-424.

Maggi, C. A., Rovero, P., Giuliani, S., Evangelista, S., Regoli, D., and Meli, A. (1990). Biological activity of N-terminal fragments of calcitonin gene-related peptide. Eur. J. Pharmacol. 179, 217-219.

Mayberg, M. R., Okada, T., and Bark, D. H. (1990). The role of hemoglobin in arterial narrowing after subarachnoid hemorrhage. J. Neurosurg. 72, 634-640.

McCulloch, J., Uddman, R., Kingman, T. A., and Edvinsson, L. (1986). Calcitonin gene-related peptide: functional role in cerebrovascular regulation. Proc. Natl. Acad. Sci. U.S.A. 83, 5731-5735.

McLatchie, L. M., Fraser, N. J., Main, M. J., Wise, A., Brown, J., Thompson, N., et al. (1998). RAMPs regulate the transport and ligand specificity of the calcitonin-receptor-like receptor. Nature 393, 333-339.

Mee, E., Dorrance, D., Lowe, D., and Neil-Dwyer, G. (1988). Controlled study of nimodipine in aneurysm patients treated early after subarachnoid hemorrhage. Neurosurgery 22, 484-491.

Meens, M. J., Compeer, M. G., Hackeng, T. M., van Zandvoort, M. A., Janssen, B. J., and De Mey, J. G. (2010). Stimuli of sensory-motor nerves terminate arterial contractile effects of endothelin-1 by CGRP and dissociation of ET-1/ET(A)-receptor complexes. PLoS ONE 5, e10917. doi: 10.1371/journal.pone.0010917

Meens, M. J., Mattheij, N. J., van Loenen, P. B., Spijkers, L. J., Lemkens, P., Nelissen. J, et al. (2012). G-protein betagamma subunits in vasorelaxing and anti-endothelinergic effects of calcitonin gene-related peptide. $\mathrm{Br}$. J. Pharmacol. 166, 297-308.

Mulderry, P. K., Ghatei, M. A., Spokes, R. A., Jones, P. M., Pierson, A. M. Hamid, Q. A., etal. (1988). Differential expression of alpha-CGRP and beta-CGRP by primary sensory neurons and enteric autonomic neurons of the rat. Neuroscience 25, 195-205.

Neil-Dwyer, G., Mee, E., Dorrance, D. and Lowe, D. (1987). Early intervention with nimodipine in subarachnoid haemorrhage. Eur. Heart J. 8(Suppl. K), 41-47.

Nelson, M. T., Huang, Y., Brayden, J. E., Hescheler, J., and Standen, N. B. (1990). Arterial dilations in response to calcitonin gene-related peptide involve activation of $\mathrm{K}^{+}$channels Nature 344, 770-773.

Nozaki, K., Kikuchi, H., and Mizuno, N. (1989a). Changes of calcitonin gene-related peptide-like immunoreactivity in cerebrovascular nerve fibers in the dog after experimentally produced subarachnoid hemorrhage. Neurosci. Lett. 102, 27-32.

Nozaki, K., Uemura, Y., Okamoto, S., Kikuchi, H., and Mizuno, N. (1989b). Relaxant effect of calcitonin generelated peptide on cerebral arterial spasm induced by experimental subarachnoid hemorrhage in dogs. $J$. Neurosurg. 71, 558-564.

Ohkuma, H., Fujita, S., and Suzuki, S. (2002). Incidence of aneurysmal subarachnoid hemorrhage in Shimokita, Japan, from 1989 to 1998. Stroke 33, 195-199.
Ohkuma, H., Tsurutani, H., and Suzuki, S. (2001). Incidence and significance of early aneurysmal rebleeding before neurosurgical or neurological management. Stroke 32, 1176-1180.

Padilla, B. E., Cottrell, G. S., Roosterman, D., Pikios, S., Muller, L., Steinhoff, M., etal. (2007). Endothelin-converting enzyme-1 regulates endosomal sorting of calcitonin receptor-like receptor and betaarrestins. J. Cell Biol. 179, 981-997.

Petermann, J. B., Born, W., Chang, J. Y., and Fischer, J. A. (1987). Identification in the human central nervous system, pituitary, and thyroid of a novel calcitonin gene-related peptide, and partial amino acid sequence in the spinal cord. J. Biol. Chem. 262, 542-545.

Pierce, K. L., Premont, R. T., and Lefkowitz, R. J. (2002). Seventransmembrane receptors. Nat. Rev. Mol. Cell Biol. 3, 639-650.

Pluta, R. M. (2005). Delayed cerebral vasospasm and nitric oxide: review, new hypothesis, and proposed treatment. Pharmacol. Ther. 105, 23-56.

Pluta, R. M., Dejam, A., Grimes, G. Gladwin, M. T., and Oldfield, E. H. (2005). Nitrite infusions to prevent delayed cerebral vasospasm in a primate model of subarachnoid hemorrhage. JAMA 293, 1477-1484.

Pluta, R. M., Thompson, B. G., Dawson, T. M., Snyder, S. H., Boock, R. J., and Oldfield, E. H. (1996). Loss of nitric oxide synthase immunoreactivity in cerebral vasospasm. J. Neurosurg. 84 , 648-654.

Polin, R. S., Bavbek, M., Shaffrey, M. E., Billups, K., Bogaev, C. A., Kassell, N. F., et al. (1998). Detection of soluble E-selectin, ICAM-1, VCAM1 , and L-selectin in the cerebrospinal fluid of patients after subarachnoid hemorrhage. J. Neurosurg. 89, 559-567.

Poyner, D. (1995). Pharmacology of receptors for calcitonin gene-related peptide and amylin. Trends Pharmacol. Sci. 16, 424-428.

Poyner, D. R., Sexton, P. M., Marshall, I., Smith, D. M., Quirion, R., Born, W., et al. (2002). International Union of Pharmacology. XXXII. The mammalian calcitonin gene-related peptides, adrenomedullin, amylin, and calcitonin receptors. Pharmacol. Rev. 54, 233-246.

Queen, L. R., Xu, B., Horinouchi, K., Fisher, I., and Ferro, A. (2000) beta(2)-adrenoceptors activate nitric oxide synthase in human platelets. Circ. Res. 87, 39-44.

Quirion, R., Van Rossum, D., Dumont, Y., St-Pierre, S., and Fournier, A. (1992). Characterization of CGRP1 and CGRP2 receptor subtypes. Ann. N. Y. Acad. Sci. 657, 88-105.

Sams-Nielsen, A., Orskov, C., and Jansen-Olesen, I. (2001). Pharmacological evidence for CGRP uptake into perivascular capsaicin sensitive nerve terminals. Br. J. Pharmacol. 132, 1145-1153.

Santhanam, A. V., Smith, L. A., Akiyama, M., Rosales, A. G., Bailey, K. R., and Katusic, Z. S. (2005). Role of endothelial NO synthase phosphorylation in cerebrovascular protective effect of recombinant erythropoietin during subarachnoid hemorrhageinduced cerebral vasospasm. Stroke 36, 2731-2737.

Satoh, M., Perkins, E., Kimura, H., Tang, J., Chun, Y., Heistad, D. D., et al. (2002). Posttreatment with adenovirus-mediated gene transfer of calcitonin gene-related peptide to reverse cerebral vasospasm in dogs. $J$. Neurosurg. 97, 136-142.

Seifert, V., Loffler, B. M., Zimmermann, M., Roux, S., and Stolke, D. (1995). Endothelin concentrations in patients with aneurysmal subarachnoid hemorrhage. Correlation with cerebral vasospasm, delayed ischemic neurological deficits, and volume of hematoma. J. Neurosurg. 82, 55-62.

Sexton, P. M., Morfis, M., Tilakaratne, N., Hay, D. L., Udawela, M., Christopoulos, G., et al. (2006). Complexing receptor pharmacology: modulation of family B G proteincoupled receptor function by RAMPs. Ann. N. Y. Acad. Sci. 1070, 90-104.

Sexton, P. M., Poyner, D. R., Simms, J., Christopoulos, A., and Hay, D. L. (2009). Modulating receptor function through RAMPs: can they represent drug targets in themselves? Drug Discov. Today 14, 413-419.

Shibuya, M., Suzuki, Y., Sugita, K., Saito, I., Sasaki, T., Takakura, K., et al. (1992). Effect of AT877 on cerebral vasospasm after aneurysmal subarachnoid hemorrhage. Results of a prospective placebo-controlled double-blind trial. J. Neurosurg. 76, 571-577.

Steenbergh, P. H., Hoppener, J. W., Zandberg, J., Lips, C. J., and Jansz, H. S. (1985). A second human calcitonin/CGRP gene. FEBS Lett. 183, 403-407.

Steenbergh, P. H., Hoppener, J. W., Zandberg, J., Visser, A., Lips, C. J., and Jansz, H. S. (1986). Structure and expression of the human calcitonin/CGRP genes. FEBS Lett. 209, 97-103.

Struthers, A. D., Brown, M. J., Macdonald, D. W., Beacham, J. L., Stevenson, J. C., Morris, H. R., et al. (1986). 
Human calcitonin gene related peptide: a potent endogenous vasodilator in man. Clin. Sci. (Lond.) 70, 389-393.

Sugawara, T., Ayer, R., Jadhav, V., Chen, W., Tsubokawa, T., and Zhang, J. H. (2011). Mechanisms of statin treatment in cerebral vasospasm. Acta Neurochir. Suppl. 110, 9-11.

Sullivan, G. W., Sarembock, I. J., and Linden, J. (2000). The role of inflammation in vascular diseases. J. Leukoc. Biol. 67, 591-602.

Takizawa, T., Tada, T., Kitazawa, K., Tanaka, Y., Hongo, K., Kameko, M., et al. (2001). Inflammatory cytokine cascade released by leukocytes in cerebrospinal fluid after subarachnoid hemorrhage. Neurol. Res. 23, 724-730.

The ACROSS Group. (2000). Epidemiology of aneurysmal subarachnoid hemorrhage in Australia and New Zealand: incidence and case fatality from the Australasian Cooperative Research on Subarachnoid Hemorrhage Study (ACROSS). Stroke 31, 1843-1850.

Thomas, J. E., Nemirovsky, A., Zelman, V., and Giannotta, S. L. (1997). Rapid reversal of endothelin1 -induced cerebral vasoconstriction by intrathecal administration of nitric oxide donors. Neurosurgery 40 , 1245-1249.

Toda, N., Kawakami, M., and Yoshida, K. (1991). Constrictor action of oxyhemoglobin in monkey and dog basilar arteries in vivo and in vitro. Am. J. Physiol. 260, H420-H425.

Toshima, M., Kassell, N. F., Tanaka, Y., and Dougherty, D. A. (1992). Effect of intracisternal and intravenous calcitonin gene-related peptide on experimental cerebral vasospasm in rabbits. Acta Neurochir. (Wien) 119, 134-138.

Toyoda, K., Faraci, F. M., Watanabe, Y., Ueda, T., Andresen, J. J., Chu, Y., et al. (2000). Gene transfer of calcitonin gene-related peptide prevents vasoconstriction after subarachnoid hemorrhage. Circ. Res. 87, 818-824.

Tran Dinh, Y. R., Debdi, M., Couraud, J. Y., Creminon, C., Seylaz, J., and Sercombe, R. (1994). Time course of variations in rabbit cerebrospinal fluid levels of calcitonin gene-related peptide- and substance P-like immunoreactivity in experimental subarachnoid hemorrhage. Stroke 25, 160-164.

Tseng, M. Y., Czosnyka, M., Richards, H., Pickard, J. D., and Kirkpatrick, P. J. (2005). Effects of acute treatment with pravastatin on cerebral vasospasm, autoregulation, and delayed ischemic deficits after aneurysmal subarachnoid hemorrhage: a phase II randomized placebo-controlled trial. Stroke 36, 1627-1632.

Tseng, M. Y., Hutchinson, P. J., Czosnyka, M., Richards, H., Pickard, J. D., and Kirkpatrick, P. J. (2007). Effects of acute pravastatin treatment on intensity of rescue therapy, length of inpatient stay, and 6-month outcome in patients after aneurysmal subarachnoid hemorrhage. Stroke 38, 1545-1550.

Uddman, R., Edvinsson, L., Ekblad, E., Hakanson, R., and Sundler, F
(1986). Calcitonin gene-related peptide (CGRP): perivascular distribution and vasodilatory effects. Regul. Pept. 15, 1-23.

van Gijn, J., Kerr, R. S., and Rinkel, G. J. (2007). Subarachnoid haemorrhage. Lancet 369, 306-318.

Vikman, P., Beg, S., Khurana, T. S., Hansen-Schwartz, J., and Edvinsson, L. (2006). Gene expression and molecular changes in cerebral arteries following subarachnoid hemorrhage in the rat. J. Neurosurg. 105 , 438-444.

Walker, C. S., Conner, A. C., Poyner, D. R., and Hay, D. L. (2010). Regulation of signal transduction by calcitonin gene-related peptide receptors. Trends Pharmacol. Sci. 31, 476-483.

Welty, T. E. (1987). Use of nimodipine for prevention and treatment of cerebral arterial spasm in patients with subarachnoid hemorrhage. Clin. Pharm. 6, 940-946.

Wickman, G., Lan, C., and Vollrath, B. (2003). Functional roles of the Rho/Rho kinase pathway and protein kinase $\mathrm{C}$ in the regulation of cerebrovascular constriction mediated by hemoglobin: relevance to subarachnoid hemorrhage and vasospasm. Circ. Res. 92, 809-816.

Wiley, J. W., Gross, R. A., and Macdonald, R. L. (1992). The peptide CGRP increases a high-threshold $\mathrm{Ca}^{2+}$ current in rat nodose neurones via a pertussis toxin-sensitive pathway. $J$. Physiol. 455, 367-381.

Wilkins, R. H. (1990). Cerebral vasospasm. Crit. Rev. Neurobiol. 6, 51-77.
Winn, H. R., Richardson, A. E., and Jane, J. A. (1977). The long-term prognosis in untreated cerebral aneurysms: I. The incidence of late hemorrhage in cerebral aneurysm: a 10-year evaluation of 364 patients. Ann. Neurol. 1, 358-370.

Zwienenberg-Lee, M., Hartman, J., Rudisill, N., and Muizelaar, J. P. (2006). Endovascular management of cerebral vasospasm. Neurosurgery 59, S139-S147.

Conflict of Interest Statement: The authors declare that the research was conducted in the absence of any commercial or financial relationships that could be construed as a potential conflict of interest.

Received: 23 July 2012; accepted: 24 October 2012; published online: 15 November 2012.

Citation: Kokkoris S, Andrews $P$ and Webb DJ (2012) Role of calcitonin generelated peptide in cerebral vasospasm, and as a therapeutic approach to subarachnoid hemorrhage. Front. Endocrin. 3:135. doi: 10.3389/fendo.2012.00135

This article was submitted to Frontiers in Neuroendocrine Science, a specialty of Frontiers in Endocrinology.

Copyright (c) 2012 Kokkoris, Andrews and Webb. This is an open-access article distributed under the terms of the Creative Commons Attribution License, which permits use, distribution and reproduction in other forums, provided the original authors and source are credited and subject to any copyright notices concerning any third-party graphics etc. 